\title{
INDIGENOUS CITY FIELDTRIP A RESOURCE GUIDE TO RYERSON UNIVERSITY
}

\author{
by \\ Jeremie Caribou and Rachel Reesor
}

Supervisor:

Harald Bauder

Advisors:

Hayden King and Reena Tandon

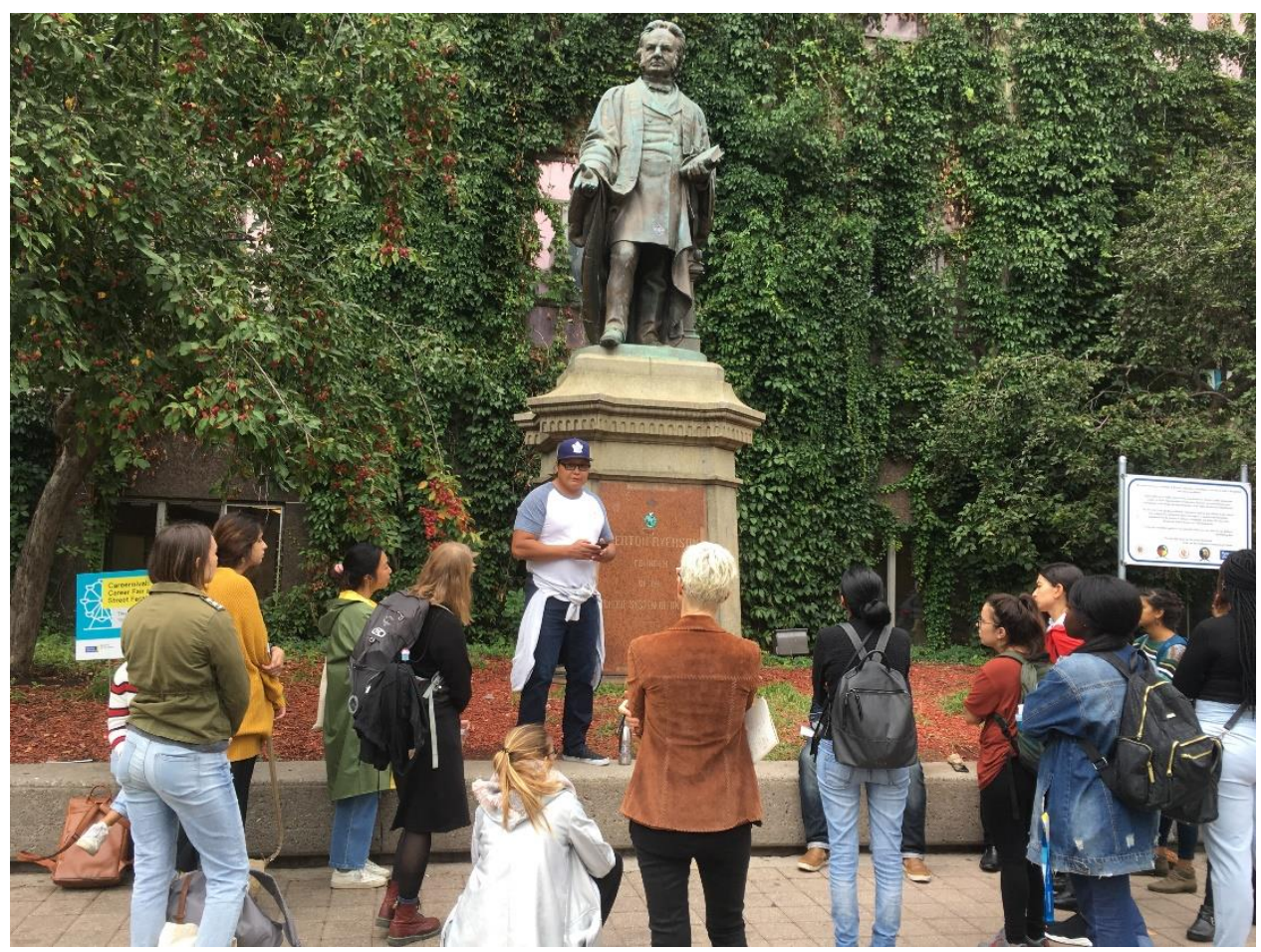

Jeremie Caribou in font of Edgerton Ryerson's statue, delivering the fieldtrip to students of the Graduate Program in Immigration and Settlement Studies 


\section{Table of Content}

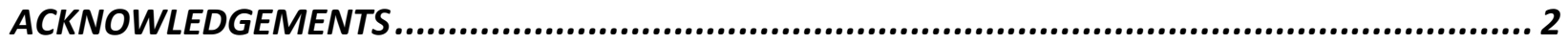

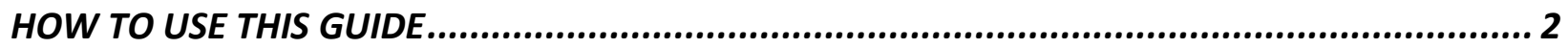

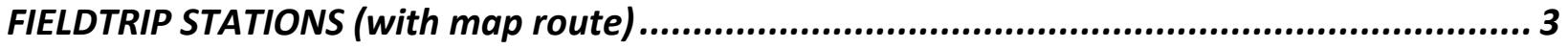

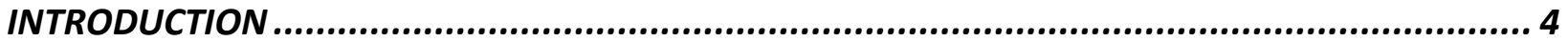

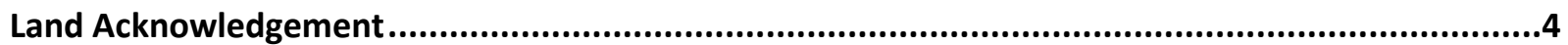

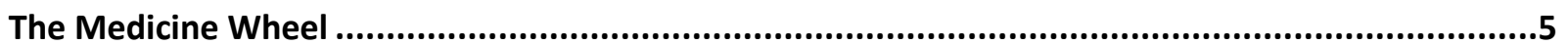

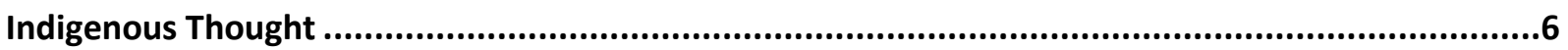

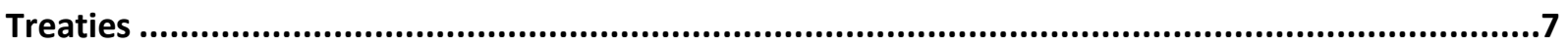

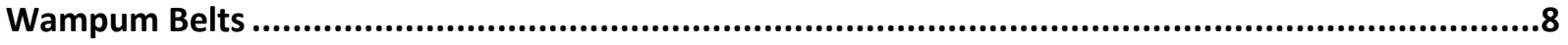

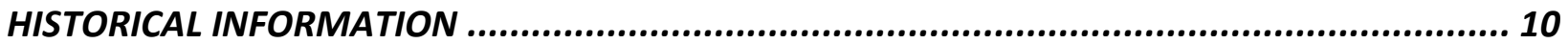

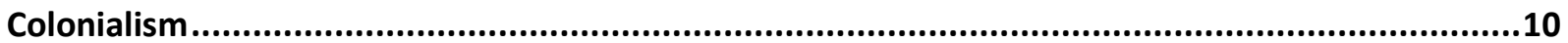

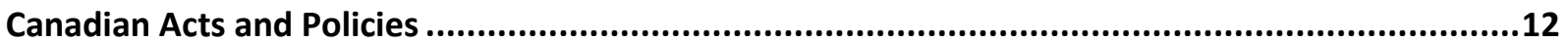

Beaver War or Iroquois Wars 1642-1698

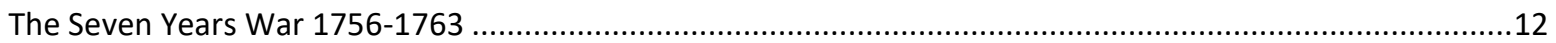

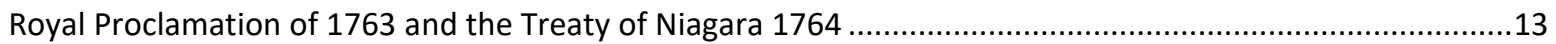

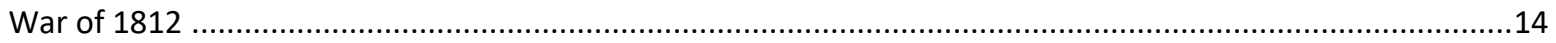

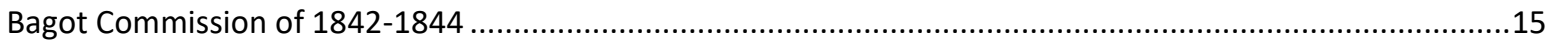

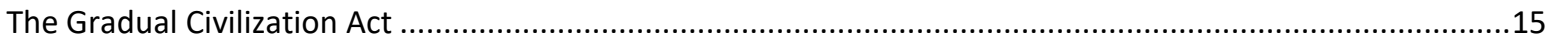

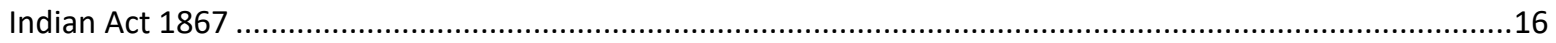

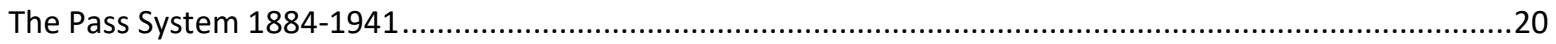

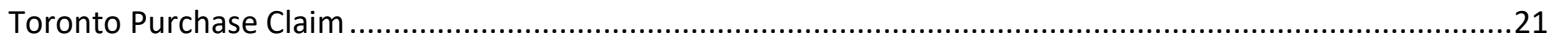

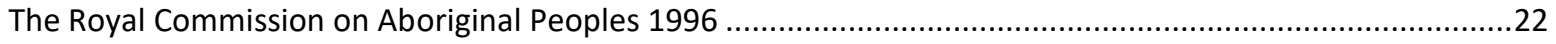

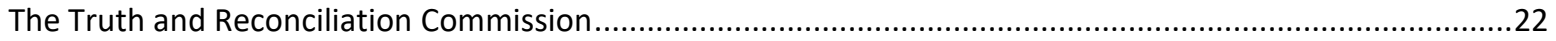

Principles respecting the Government of Canada's relationship with Indigenous peoples.............................22

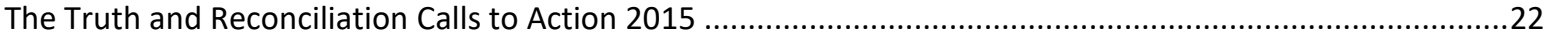

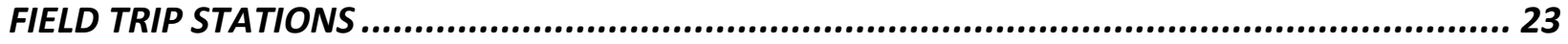

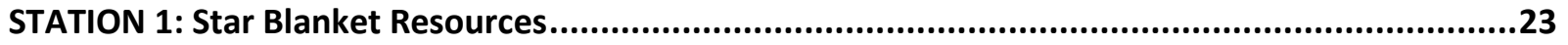

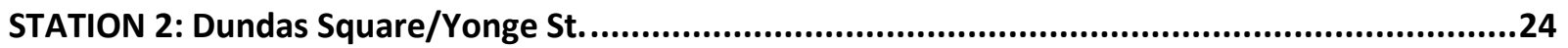

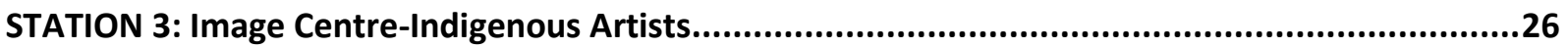

STATION 4: Egerton Ryerson Statue and TRC plaque .................................................................27

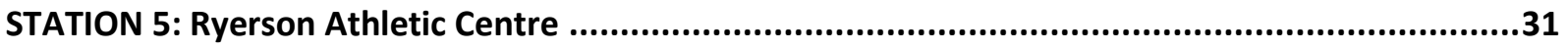

STATION 6: Ryerson Aboriginal Student Services (RASS) ............................................................33

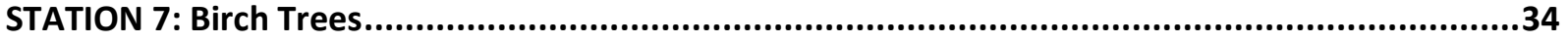

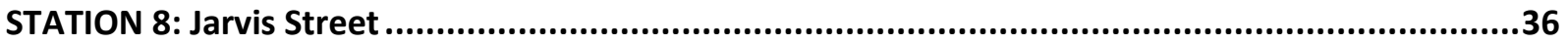

STATION 9: Miziwe Biik Aboriginal Employment \& Training.....................................................38

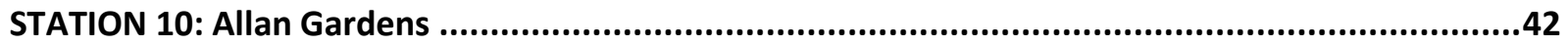




\section{ACKNOWLEDGEMENTS}

We thank Jon Johnson and Serena Johnson from First Story Toronto for their guidance, suggestions, and information about areas around Ryerson. Their First Story Toronto app was extremely helpful in further developing our resource list. We also thank Hayden King, advisor to the Dean on Indigenous Education in the Faculty of Arts and Executive Director of the Yellowhead Institute, for his support and guidance through the development of this resource guide, and Reena Tandon, Faculty of Arts, for her suggestions and ideas. A special thank you to Harald Bauder, Director of the Graduate Program in Immigration and Settlement Studies, for being our advisor and guiding us through the development process of this fieldtrip guide. Sharyne Williams helped formatting this document.

Funding was provided by the Graduate Program in Immigration and Settlement Studies and the Faculty of Arts at Ryerson University.

\section{Ryerson \\ University \\ Immigration \& Settlement Studies Graduate Studies}

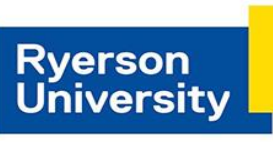

\section{Faculty \\ of Arts}

\section{HOW TO USE THIS GUIDE}

This resource guide contributes to a knowledge base of events, facts, interpretations, and relationships relating to Indigenous peoples with a particular focus on the land that is currently occupied by Ryerson University. This knowledge base is available for free to anyone who wishes to learn about or educate others about this topic. We realize that nobody "owns" this knowledge but that knowledge is always embodied and situated in personal experiences. Please use and share this knowledge responsibly and with respect.

The guide is intended to facilitate walking fieldtrips involving particular sites (i.e. "stations") located on or close to Ryerson campus. For each station, we identified several resources and included links to original sources. We structured this guide by listing the sources followed by a brief description of the information from the source in bullet form. This brief description does not replace reading the original source but is rather intended to help the reader navigate the guide.

We envision several ways in which this guide can be used: it can be used as a selfguided tour; it can be used by the community organizations and Ryerson instructors to develop fieldtrips to be delivered to their classes or other audiences; or it can be used by students and the wider community to learn about Indigenous peoples and their relationship to Ryerson University. 


\section{FIELDTRIP STATIONS (with map route)}

Station 1- JOR- Jorgensen Hall entrance - STAR BLANKET

Station 2- Dundas Square - DUNDAS AND YONGE ST.

Station 3- 33 Gould St. - RYERSON IMAGE CENTER

Station 4-Gould St. -EGERTON RYERSON STATUE AND TRC PLAQUE

Station 5-50 Gould St. -RYERSON ATHLETIC CENTER

Station 6- KHW-Kerr Hall West 389- RYERSON ABORIGINAL STUDENT SERVICES

Station 7- By Pitman Hall Residence on Church St.- BIRCH TREES

Station 8- Jarvis St. -JARVIS ST.

Station 9- 167 Gerrard St. E. -MIZIWE BIIK ABORIGINAL EMPLOYMENT AND

TRAINING

Station 10- Gerrard St. \& Jarvis St. -ALLAN GARDENS

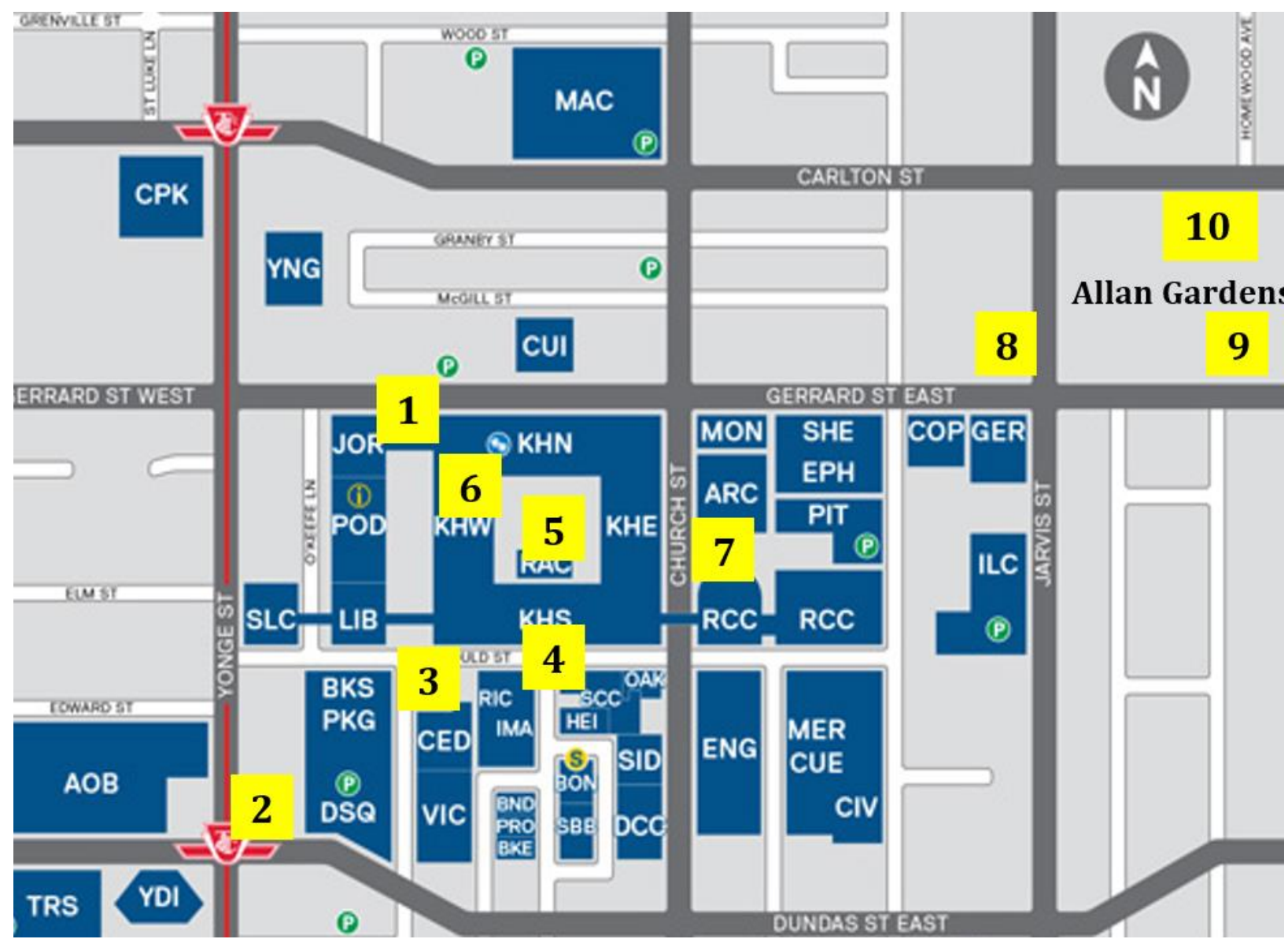

Note: The order of the stations can be modified and stations can be omitted or added depending on your preferences. 


\section{INTRODUCTION}

\section{Land Acknowledgement}

Ryerson University Office of the Vice-President, Equity \& Community Inclusion. (2018, January). Truth and Reconciliation at Ryerson University: Building a New Foundation for Generations to Come. Community Consultation Summary Report. 1-20. Retrieved from: https://www.ryerson.ca/content/dam/aboriginal-news/Truth-and-ReconciliationCommunity-Consultation-Report-AODA.pdf?

- Ryerson Land acknowledgement and an explanation of it listed on page 3

Aboriginal Education Council Land Acknowledgement. (2016). Ryerson Land Acknowledgement. Retrieved from https://www.ryerson.ca/aec/landacknowledgement/

- "Toronto is in the 'Dish With One Spoon Territory'. The Dish With One Spoon is a treaty between the Anishinaabe, Mississaugas and Haudenosaunee that bound them to share the territory and protect the land. Subsequent Indigenous Nations and peoples, Europeans and all newcomers have been invited into this treaty in the spirit of peace, friendship and respect."

- This website explains Ryerson's land acknowledgement and when and why it was made

- Has a link to the PDF file of the Ryerson Land Acknowledgement Statement which has a bit more detail

Lytwyn, V. (1997). A Dish with One Spoon: The Shared Hunting Grounds Agreement in the Great Lakes and St. Lawrence Valley Region. Papers of the Twenty-Eighth Algonquian Conference. 28. 210- 227. Retrieved from https://ojs.library.carleton.ca/index.php/ALGQP/article/view/507

- The words dish with one spoon and other similar terms have been used since time immemorial by Aboriginal people in the Great Lakes and St. Lawrence valley region and some nations believe that this is the first constitution between nations before colonization

- The 'Dish With One Spoon' treaty were agreements concerning the shared hunting grounds

- The treaty was enshrined in the Royal Proclamation of 1764 and announced many times afterward

- The dish symbolizes a common hunting ground, while the spoon denotes that people are free to hunt within it and to eat the game and fish together

- Agreements between Indigenous nations to share hunting grounds predate written records, but their antiquity is memorialized in rich oral traditions that were erased during the "Indian Residential School' era 
- Wampum belts were used to identify the significance of these agreements between Nations to share the territory for hunting or agriculture passed on by knowledge keepers from generation to generation

- Occasionally, these agreements were formalized in treaties, and after the arrival of Europeans in North America the words were translated and recorded by French, Dutch and English

Johnston, D. (2006). Connecting People to Place: Great Lakes Aboriginal History in Cultural Context. Ipperwash Inquiry. Retrieved from https://papers.ssrn.com/sol3/papers.cfm?abstract id=1864900

- These are recommended land acknowledgements that have been developed by local university-based Indigenous councils or advisory groups

- The goal is to encourage all academic staff association representatives and members to acknowledge the First Peoples on whose traditional territories we live and work

- Acknowledging territory shows recognition of and respect for Aboriginal Peoples. It is recognition of their presence both in the past and the present

- Recognition and respect are essential elements of establishing healthy, reciprocal relations

- These relationships are key to reconciliation, a process to which CAUT is committed

Canadian Association of University Teachers. (2018). Guide to AcknowledgingFirstPeoples \& Traditional Territory. Retrieved fromhttps://www.caut.ca/content/guide-acknowledging-first-peoples-traditionalterritory

- General knowledge about land acknowledge across Canada

\section{The Medicine Wheel}

We take no ownership over this information and knowledge that was respectfully gained in a good way through knowledge sharing and learning by attending cultural camps and teachings in the Indigenous community.

Indigenous people have been practicing their own belief systems, that connected them to all aspects of each person's daily activities, for thousands of years. These belief systems honoured and respected the connection to the land, the universe, and one another-experiences that were individual and transformative. Traditional knowledge and sustenance gained by observing the natural world of plant and animal life. This knowledge, as it continues to develop, advance, and adapt over time, is passed down from generation to generation through traditional oral teachings

The Medicine Wheel also known as the Sacred Circle or Hoop, has been used by generations of various First Nations peoples for health and healing. First Nations consider the Medicine Wheel as the holistic approach of an individual's overall health 
and well-being. It embodies the Four Directions or Quadrants that represent the spirit, physical, mental, and emotional aspect of one's health. When one of these aspects lack or is out of balance, there are significant consequences in a person's overall social and physical well-being.

\section{The four directions or quadrants are:}

- The North represents the Spirit; it is a practice and a way of life and is represented by the traditional medicine sweetgrass; when braided it represents the mind, body, and spirit.

- The East represents the Physical side of things, and the traditional medicine is tobacco; used for offerings, tobacco ties and for ceremonial pipes, ceremonies

- The South represents Mentality. By being mindful and respectful of all aspects of your daily activities represented by the traditional medicine of cedar; used as a medicine for tea as it is high in Vitamin C

- The West represents Emotion and the sense of safety, belonging, and human comfort. The traditional medicine used and placed in the medicine wheel is sage which calms the heart to purify the mind; it is used for smudging and ceremonies.

\section{All these medicines can be used for smudging and ceremonies depending on the ceremony.}

- If you want to do a symbolic or significant ceremony, tobacco or a gift is usually passed to a local Indigenous elder to come and facilitate the ceremony. But if you just want to start something in a good way such as meetings, teachings, sharing circles, etc. Indigenous people would smudge first then begin their agendas.

- Smudging can be related to other cultures or traditions. For example, other cultures like Christianity, Buddhism, Hinduism, Islam, Judaism, etc. burn incense for their own purposes.

- Sage is the medicine that is mainly used for smudging. It has a universal purpose so to speak. Other medicines such as cedar, tobacco, sweetgrass can be used along with sage for significant ceremonies such as sweat lodges, fasting ceremonies, sundances, etc.

\section{Indigenous Thought}

Barnhardt, R. KAwagley A.O. (2005) Indigenous Knowledge Systems/Alaska Native Ways of Knowing retrieved from http://www.ankn.uaf.edu/curriculum/Articles/BarnhardtKawagley/Indigenous Kno wledge.html

- This article seeks to extend our understanding of the processes of learning that occur within and at the intersection of diverse world views and knowledge systems, drawing on experiences derived from across Fourth World contexts, with an emphasis on the Alaska context in particular

- The article outlines the rationale behind a comprehensive program of educational initiatives that are closely articulated with the emergence of a new generation of indigenous scholars who are seeking to move the role of indigenous knowledge 
and learning from the margins to the center of the educational research arena and thus take on some of the most intractable and salient issues of our times

\section{Treaties}

Hall, A. J. (2017) Treaties with Indigenous Peoples in Canada. The Canadian Encyclopedia. Retrieved from https://www.thecanadianencyclopedia.ca/en/article/aboriginal-treaties

- Treaties are autonomous alliances made between the Canadian state and Indigenous peoples to share the land and the resources that come with the land

Bickerton, J., Gagnon, A. G. (2014). Canadian Politics. Sixth Edition. Retrieved from pp.3-88. University of Toronto Press.

- Prior to contact, treaty federalism existed between First Nations governing shared territories that have never been relinquished

- This influenced nation to nation alliances between Indigenous and nonIndigenous peoples

Frideres, J. S., Gadacz, R. R. (2001). Aboriginal Peoples in Canada. Sixth Edition. Retrieved from pp. 230-260, pp. 296-323, pp. 351-382. Pearson Education Canada Inc. Toronto, Canada

- Indigenous inherent right to self-government consists of cultural, social, and economic development control

- The right to self-government is protected and entrenched into section 35 of the constitution, treaties, court decisions, and royal prerogatives

- Despite alliances and inherent rights entrenched into the constitution to share the land and its resources, the federal government continues to fail to address social and economical Indigenous issues

- This can be due to the lack of Indigenous representation and perspective at all levels of government

Treaties are constitutionally recognized current and historical agreements made between the Canadian state and Indigenous peoples' that acknowledge and affirm inherent titles and rights to self-determination regarding lands, resources, and culture. Indigenous inherent title is a unique collective right of practices and control over their ancestral territories. The right to self-determination is the right to practice, unmolested as an existing and autonomous sovereign nation or a third order of government within the Canadian Constitution. 


\section{Wampum Belts}

- Wampum refers to white and purple beads from the Algonquian word "Wampumpeague" meaning a "string of white shell beads" and used as currency during the fur trade in Dutch and English colonies until the 1660's

- Wampums are visual memory keepers recording history and communicating ideas

- Beaded patterns represent a person, nation, event, invitation, shared values, and understandings/agreements between two or more parties.

- Traditional wampum belts were used as covenants and petitions for understanding

- Words spoken during an agreement are made into wampums to be used for ceremony, teaching, and reminders of law and values

- The Haudenosaunee used wampum belts of varying in size for diplomatic meetings (treaties) with Europeans and other First Nations

- From the early $17^{\text {th }}$ century until the early $19^{\text {in }}$ century, Wampum belts were used to record and legitimize formal or international agreements (treaties) between nations

- Some Wampum belts have been kept and preserved for the significant value they possess, such as oral agreements (treaties) made between nations concerning shared land and territory

- To prevent the value of oral agreements (treaties) translated through Wampum belts, agreements were occasionally announced publicly to community members

- Wampum belts were used to identify the significance of treaties between nations to share the territory for hunting or agriculture. Passed on by knowledge keepers from generation to generation

- The white and purple beads mapped out the dialogue of the treaty and announced

\section{https://thediscoverblog.com/2015/04/28/wampum-belts/}

- Wampum belts are sacred objects to First Nations, encrypted with historical knowledge passed on from generation to generation

\section{https://www.clo-ocol.gc.ca/en/cyberbulletin newsletter/2011/may-24}

- Wampum is a graphic memory marker possessing influential power and meaning

- Made with quahog clam shells which are the purple or black, and whelk shells which are white

- The white whelk shell is a symbol of power and peace and all the good things, and the purple or black quahog clam shell is just the opposite

- Existing Treaties made before and after contact are living documents transmitted through Wampum belts 
- At a Crown-First Nations meeting in 2012, the Governor General and Commander-In-Chief of Canada was honoured to be presented a sacred gift of friendship and diplomacy in the form of a wampum belt

- He mentioned the wampum belt releases a symbolic presence at Rideau Hall representing the unique Crown-Indigenous relationship http://www.gg.ca/en/media/news/2012/presentation-commemorative-war-1812medal-and-banner-first-nations-and-metis-communities-0

\section{DISH WITH ONE SPOON}

- The 'Dish with One Spoon' wampum belt is the oldest existing treaty concerning shared hunting grounds and territories made between Indigenous Nations before first contact

- Agreements between Indigenous nations to share hunting grounds predate written records shared through rich oral traditions erased during the 'Residential School' era

https://ojs.library.carleton.ca/index.php/ALGQP/article/view/507/409

\section{TWO ROW WAMPUM BELT}

- The Belt represents the river of life, and the two rows of purple represents vessels that are autonomous sovereign nations that will travel down the river and not interfere with each other's vessel. The white represents peace, friendship, and respect

- The Two Row Wampum belt is the first agreement (treaty) between Indigenous and European nations based on the three principles of peace, friendship and forever

- It forms the foundation of all treaty relationships made by the Haudenosaunee with other Indigenous and European governments enshrined into the Royal Proclamation/Treaty of Niagara in 1764

- 2013, the Two Row Wampum belt marked the 400 anniversary of the first agreement (treaty) between Indigenous and European nations

- Wampum belts identified and translated significant events, mapping out the process of all treaties leading up to this moment between all Indigenous and European nations

\section{http://honorthetworow.org/learn-more/history/}

\section{COVENANT CHAIN WAMPUM BELT}

- The Treaty of Niagara Covenant Chain Wampum Belt of 1764 established the existing Crown Indigenous relationship that is still relevant to this day 
https://torontopubliclibrary.typepad.com/trl/2018/09/wampum-not-museumartifacts-original-treaties.html

\section{PLEDGE OF THE CROWN WAMPUM BELT}

- Pledge of the Crown Wampum Belt was created by the British representing the ongoing Crown-Indigenous relationship after the War of 1812

- The pattern may have been derived from an ancient design called the meander, or Greek Key

- It represents the interwoven bonds of love and friendship and is believed that the meander symbolises infinity or the eternal flow of things

- The "Pledge to the Crown Wampum Belt" represents past and current policies but some people translated it as they have failed to protect Indigenous peoples to this day from ongoing social injustices

\section{https://www.wampumbear.com/W War\%201812\%20Peace\%20Belt.html}

\section{HISTORICAL INFORMATION \\ Colonialism}

LaRocque, E (2014) Colonization and Racism retrieved from http://www3.nfb.ca/enclasse/doclens/visau/index.php?mode=theme\&language=english\& theme $=30662 \&$ film $=\&$ excerpt $=\&$ submode $=$ about $\&$ expmode $=2$

Goeman, M. (2013) Mark My Words Native Women Mapping Our Nations. University of Minnesota Press

The history of Canada is a history of colonization, a history that invades, deprives, and gains control of a nation that benefits the oppressor at the expense of the oppressed due to loss of lands and resources through treaty making. The oppressor turned to racism to justify the oppression by designing policies, commissions, and acts (Emma Laroque). "Imperialism and colonialism has brought complete disorder to colonized peoples, disconnecting them from their histories, their landscapes, their languages, and their social relations and their own ways of thinking, feeling, and interacting with the world" (Linda Tuhiwai Smith, 2013, p.3)

Pope Alexander VI. (1493). The Doctrine of Discovery, 1493. History Now. Retrieved from https://www.gilderlehrman.org/content/doctrine-discovery-1493

- A written document that supported Spain's right to lands "discovered" by Christopher Columbus in 1493.

Terra Nullius. Retrieved from http://homepages.gac.edu/ /wren/AmericanldentititesArt\%20folder/Americanlden tititesArt Terra\%20Nullius.html 
- Terra Nullius is Latin meaning "land belonging to nobody"

Indigenous Corporate Training Inc. (2016). Christopher Columbus and the Doctrine of Discovery-5 Things to Know. Working Effectively with Indigenous Peoples. Retrieved from https://www.ictinc.ca/blog/christopher-columbus-and-the-doctrine-of-discovery5thing-to-know

- The Doctrine of Discovery is a framework to claim territory to non-Christian land issued in 1493 and used by European monarchs to legitimize colonization

- The Doctrine considered Indigenous peoples as non-human; therefore the land was empty and considered terra nullius

- United Nations regarded the Doctrine of Discovery as 'shameful' and they stated that it was the root of all the Indigenous discrimination and marginalization occurring today

- The Doctrine of Discovery is still relevant in today's legal arenas in Canada

- The Doctrine continues to influence Indigenous peoples lives in Canada today

Sellars, B., Alfred, T., Venne, S., Manuel, A., Diabo, R. (2017). Preface \& PART I: The Machinery of Colonialism. In P. McFarlane, N. Schabus (Eds.). A Manual for Decolonization: Whose Land is it Anyway?(1-22). British Columbia: Federation of Post-Secondary Educators of BC. Retrieved from https://fpse.ca/sites/default/files/news files/Decolonization\%20Handbook.pdf

- The population of the Americas was solid, secure, and strong before and during contact. Turtle Island was a world thousands of years old where hundreds of cultures had thrived with their own governments and laws

- Turtle Island had thriving communities; sharing and contributing provided everyone a valuable place in society

- Diseases were brought to Canada, to which Indigenous peoples had no immunity. The declining Indigenous population made it easy for settlers to move in and create further rchaos in Indigenous communities

- Dispossession and racist laws have produced a long list of social problems for Indigenous peoples

- For generations Indigenous people have been in a life and death struggle to exist and will not except annihilation

- Most Canadians think Canada established formal title 151 years ago in the British North America Act (BNA). Yet, to this day negotiations between First Nations and the Crown continue to have First Nations surrender their titles and lands

- The British used/applied the Doctrine of Discovery to assert authority and jurisdiction over territories to prevent other colonizers from laying claim to the land

- Colonialism has three components: Dispossession; by depriving Indigenous peoples' of their traditional territory and segregating them to reserves. Dependence; some areas of land were particularly fertile and the Indigenous peoples were successful agricultural people and were able to grow abundant 
crops and tried to sell them. Local white farmers complained about the competition and laws were passed (Pass System) forbidding Indigenous people to sell their produce or even leaving their reserves without an authorized pass signed from an Indian Agent. Poverty is not a by-product of domination but an essential element of it. Oppression; controlling all aspects of Indigenous peoples lives and limiting their ability to provide for themselves. Commissions, policies, acts were all designed to eliminate or assimilate Indigenous peoples by death or enfranchisement

\section{Canadian Acts and Policies}

Beaver War or Iroquois Wars 1642-1698

Parrott, Z. (2006). Iroquois Wars. The Canadian Encyclopedia. Retrieved from https://www.thecanadianencyclopedia.ca/en/article/iroquois-wars/

- Series of $17^{\text {th }}$ century conflicts between Haudenosaunee Confederacy, numerous First Nations, and European colonial forces all eyeing for control of the Hudson Bay Company fur trade

- During the fur trade the Haudenosaunee began to exert their military strength when they began trading and receiving guns

- The Haudenosaunee succeeded in breaking apart all groups surrounding the Confederacy

- The Treaty of 1667 allowed the French to extend their trades north

- The Beaver Wars ended in 1701 with the Treaty of Grande Paix (Great Law of Peace), which symbolized peace, friendship, and respect, between the Haudenosaunee Confederacy and European forces

\section{The Seven Years War 1756-1763}

Belanger, C. (2005). The Seven Years' War in Canada. The Quebec History Encyclopedia. Retrieved from

http://faculty.marianopolis.edu/c.belanger/quebechistory/encyclopedia/SevenYears War-FrenchandIndianWar-TheWaroftheConquest.htm

- The Seven Years War was the final phase of the century-long war for control of North America between France and Great Britain

- The war officially began in 1756 and lasted up until a peace treaty was signed in 1763 
Borrows, John. Wampum at Niagara: The Royal Proclamation, Canadian Legal History, and Self-Government. In Aboriginal and Treaty Rights in Canada: Essays on Law, Equality, and Respect for Difference. Vancouver: University of British Columbia Press, 1997. Retrieved from https://www.sfu.ca/ palys/BorrowsWampumAtNiagara.pdf

- The article examines the events leading up to the Royal Proclamation of 1763 and the Treaty of Niagara of 1764 (Covenant Chain of Friendship), which are fundamental documents in First Nation and Legal History that have never lost their significance and value between Indigenous and non-Indigenous peoples

- Indigenous peoples used the Two Row Wampum belt to translate the significance of The Royal Proclamation which was acknowledged and honoured by Crown officials

- The Two Row Wampum Belt founded in peace, friendship, and forever is enshrined into the Royal Proclamation and the Treaty of Niagara presented by Indigenous peoples during Nation-to-Nation meetings found in 1847 colonial reports

- First Nations have kept copies of the Royal Proclamation that validates rights to self-determination, protects interests, land use, and the unique relationship Indigenous peoples have with the British Crown (Canada)

- The Royal Proclamation 1763 became the Treaty of Niagara of 1764 when the meeting was summoned to renew the nation-to-nation relationship

- Approximately 2,000 Indigenous leaders present at this meeting, symbolically established the unique relationship between Indigenous peoples and the British Crown (Canada) developed through war and treaties for control of land, resources, and jurisdiction

- The document protects and authenticates ownership of land by Indigenous peoples that have never been conquered and were autonomous to their own sovereignty, acknowledged and respected by French and British officials

Indigenous Foundations UBC. (2009). Royal Proclamation, 1763. First Nation and Indigenous Studies. Retrieved from http://indigenousfoundations.web.arts.ubc.ca/royal proclamation 1763/

- The Royal Proclamation is part of a treaty between First Nations and the Crown that guarantees First Nations right to self-government

- King George III in 1763 to officially claim British territory in North America after Britain won the Seven Years War

- Ownership of North America is given to King George

- The Royal Proclamation, ownership over North America is issued to King George but it explicitly states that Aboriginal title has existed and continues to exist, and that all land would be considered Aboriginal land until ceded by treaty

- Only the Crown can buy land from First Nations 
- First step toward the recognition of existing Aboriginal rights and title

- The Royal Proclamation set a foundation for the process of establishing treaties

- Designed by British colonists without Aboriginal input

\section{War of 1812}

Indigenous and Northern Affairs Canada. (2016). Indigenous Contributions to the War of 1812. Aboriginal History in Canada. Retrieved from http://www.aadncaandc.gc.ca/eng/1338906261900/1338906300039

- Before Canada became a country, a key part of the defensive network of British North America was Britain's military alliances with First Nations

- During the War of 1812 First Nations warriors and Metis fighters helped defend British territories from American forces

- Thousands of First Nation and Metis warriors fought beside British troops

- Both the British and First Nations and Metis resisted against American expansion

Indigenous and Northern Affairs Canada. (2016). Exhibit: Aboriginal Contributions to the War of 1812. Aboriginal History in Canada. Retrieved from http://www.aadncaandc.gc.ca/eng/1348771334472/1348771382418\#chp1a

- Great Britain's unique relationship and support with First Nation's claim to territory in the American Midwest along with overlapping territorial were contributing factors when the United States officially declared war on Great Britain June 18th, 1812

- British military strength in North America was not ideal when the United States declared war on Great Britain due to being engaged in warfare with Napoleon in Europe

- Britain's alliances with numerous First Nations including Metis were key elements for successfully defending invasions by the United states, which was acknowledged, honoured, and respected by Great Britain

- First Nations military leaders such as Tecumseh, Jon Brant, Chief Oshawana, Teyoninhokarawen (The Snipe), and Wabasha recruited Indigenous warriors to fight alongside Major-General Brock and Great Britain's war campaign and defence against the United States

- The end of the war marked a shift in Indian Policy: British stopped cultivating military alliances with First nations and the Indian Department renewed the process of obtaining Indian land in order to grow settlement

- Even though First Nations helped the British to keep and defend Canadian soil, assimilation policies were developed after the war that had devastating effects on the First Nation people

- First Nation were forced onto reserves so that settlers could take over the land and policies were made to "kill the Indian in the child" by removing the sons and daughters of native people to residential schools 


\section{Bagot Commission of $1842-1844$}

Rheault, A. (2011). Solving the "Indian Problem." Assimilation Laws, Practices \& Indian Residential Schools. Ontario Metis Family Records Center. Retrieved from https://www.omfrc.org/wp-content/uploads/2016/06/specialedition8.pdf

- Established by Sir Charles Bagot, Governor General of British North America

- The commission forced Native people on to reserves where they were given agricultural tools and livestock to perform European farming methods

- Form of assimilation and removal of land

- This commission proposed federally run Indian residential schools as a good tool for separating children from their parents and forcing Aboriginal peoples away from their traditional life

- Enforced Native people to choose citizenship or Indian status; this created disenfranchising most Indian and Metis people in Canada by forcing British citizenship upon them and completely erasing tribal identity and nationality

- 1846 - Indian Affairs Superintendent P.G. Anderson stated: "it is because you do not feel, or know the value of education; you would not give up your idle roving habits, to enable your children to receive instruction. Therefore you remain poor, ignorant and miserable. It is found you cannot govern yourself. And if left to be guided by your own judgment, you will never be better off than you are at the present; and your children will ever remain in ignorance. It has therefore been determined, that your children shall be sent to Schools, where they will forget their Indian habits and be instructed in all the necessary arts of civilized life, and become one with your white brethren." (p. 1)

Ryerson University's Aboriginal Education Council (2010, August). Egerton Ryerson, theResidential School System and Truth and Reconciliation. 1-7. Retrieved from https://www.ryerson.ca/aec/about/

- Bagot report of 1842 is viewed as the starting point of residential schools (p. 2)

- It brought about the assimilative policy and eventually residential schools (p. 2)

\section{The Gradual Civilization Act}

Robinson, A. (2016). Gradual Civilization Act. The Canadian Encyclopedia. Retrieved from https://www.thecanadianencyclopedia.ca/en/article/gradual-civilization-act/

- Passed by the $5^{\text {th }}$ Parliament of the Province of Canada in 1857

- Part of the states effort to use government policy to assimilate Indigenous peoples to the economic and social customs of European settler society

- Indigenous people could not obtain land or receive a land grant from the federal government unless they were an "educated Indian" or of "good moral character"

- Indigenous people were expected to relinquish their treaty rights voluntarily, to be replaced by land parceled out for homesteading and voting privileges 
- The 1857 Act set a precedent for further paternalistic laws, like the Gradual Enfranchisement Act of 1869, which also sought to regulate Indigenous self determination

- These Acts were placed under the Indian Act in 1876 which sidestepped the rights of Indigenous peoples under the Royal Proclamation of 1763

- This and other Acts were blatantly racist and lacked regard for the sovereignty of indigenous people

- These Acts were in place to diminish Indigenous power in order to fulfill the expansionist desire of the growing Canadian state

- The larger effort to strip Indigenous peoples of their rights under the repressive policies represented cultural genocide

\section{$\underline{\text { Indian Act } 1867}$}

Indigenous Foundations UBC. (2009). Indian Act, 1763. First Nation and Indigenous Studies. Retrieved from

https://indigenousfoundations.web.arts.ubc.ca/the indian act/\#billc31

- Act that allows or does not allow someone to be federally recognized as an Indian either in Canada or the United States

- Ways of understanding Native identity in relation to the government

- The Canadian federal government regulates and administers the affairs and dayto-day lives of registered Indians and reserve communities

- Administered by Indian and Northern Affairs Canada (INAC)

- Long history of assimilation policies

- Non-Native colonists wanted Indigenous people to shift from economic system of redistribution to one of private property ownership so certain things were banned through the Indian Act to remove their culture and way of life

- Section 141 - outlawed Indigenous people to fight for their rights through the legal system

- 1951 Amendments United Nations' Universal Declaration of Human Rights led to this revision of the Indian Act; no longer illegal for cultural activities; they could now hire legal counsel; moved more to the idea of Indigenous people becoming contributing citizens of Canada, although there are still many present issues

- The White Paper Policy (1969) created by Trudeau was put forward to abolish the Indian Act and allow all Indigenous people to become like other Canadian Citizens. It was rejected because Indigenous peoples did not want to join mainstream society and assimilate

- In 1985, Bill C-31 altered Section 12, which denied women Indian status if they married a non-Indian man. When the Indian Act was amended, Bill C-31 allowed those who lost their status to regain it

- 2009 Indian Act was amended so that those who lost their status and regained it have the ability to pass on their status for more than one generation

- Currently, there is Indian Status 6.1 and 6.2. Those under 6.2 status will be unable to pass on their Indian Status if they marry a non-status person and have a child 
Fenge, T. (2015) Chapter 8: Negotiation and Implementation of Modern Treaties between Aboriginal Peoples and the Crown in Right of Canada. In T. Fenge \& Aldridge J. (Eds.), Keeping Promises: The Royal Proclamation of 1763, Aboriginal Rights, and Treaties in Canada. (105-137). Montreal \& Kingston: McGill-Queen's University Press. Retrieved from https://ebookcentral-proquestcom.ezproxy.lib.ryerson.ca/lib/ryerson/reader.action?doclD=4396108\&ppg=12

- When Europeans first arrived to this continent a trading relationship quickly developed with Indigenous peoples. This relationship was managed by making agreements (Treaties)

- Treaties are managed up to this day in regards to land claims through the "modern treaties" making process between the Crown and Indigenous peoples

- The Treaty making process and relationship has been around before Canada and the United States were established as countries. The Treaties address peace, friendship, and coexistence; military alliance; trade; and economic development

- Modern Treaties are more detailed, comprehensive, complex, and challenging to negotiate

- After the Second World War, the Indian Act was amended in 1951. This removed the prohibition of Indigenous peoples to obtain legal council and to pursue legal action regarding land claims

- In 1969, Prime Minister Trudeau released the rejected "White Paper" that would extinguish 'special rights' for Indigenous peoples. The White paper suggested existing treaties were limited and minimal which denied Indigenous peoples heritage, status, identity, and treaty relationship to the Crown

- Indigenous peoples widely rejected and opposed the White Paper notably by Harold Cardinal's 'The Unjust Society'. This led to the Calder split decision of the Supreme Court of Canada that acknowledged the existence in Canadian Law of Indigenous title regardless of any grant or act of recognition by the Crown

- August 1973, Minister Chrétien announced that the Government of Canada would negotiate land claims with Aboriginal peoples who had not concluded historic treaties with the Crown and whose Aboriginal title to land had not been superseded by law

Milloy, J. Indian Act Colonialism: A Century of Dishonour, 1869-1969. Research Paper for the National Centre for First Nations Governance, 2008. Retrieved from: http://fngovernance.org/ncfng research/milloy.pdf

- With the Indian Act of 1869 , the government set out its own vision of future Canada-First Nations relations: an aggressive colonizing project of assimilation not only of First nations in those territories but of all First Nations throughout the nation

- Amendments to the 1869 Act and in new Acts, spelled out, in increasing detail, a colonial structure that passed control of First Nations people and communities into the hands of the Indian Affairs Department 
- The foundation of British policy was the historic Proclamation of 1763. The principles it laid down with respect to land and its inherent respect for the "national" character of First Nations formed the core of British-Indian relations and re-emerged in the late 1970s as the baseline of Canadian-First Nations relations

- In the Proclamation's place, the relationship between Canada and First nations was shaped by other influences and "cultural" forces rather than legal principles

- As Canada's first Prime Minister, J. A. Macdonald, informed Parliament that it was the nation's duty to "do away with the tribal system and assimilate the Indian peoples in all respects to the inhabitants of the Dominion"

- Assimilation became the enduring justification for federal colonialism

- First Nation were self-governing within their recognized jurisdictions including all internal affairs until the Indian Act of 1869

- After Confederation the responsibility for conducting relations with First Nations was shifted from the Imperial to the Federal Government

- The Act provided that any Indian judged to be educated, free from debt, and of good moral character could apply to receive land within the colony and the rights accompanying it. Now focused on assimilation

- Each successive Indian Act in the period under review carried enfranchisement provisions

- During Macdonald's government the phase "Nations...of Indians" was no longer appropriate as, in his estimation, Indians were like children; they were like "persons underage, incapable of the management of their own affairs" and, therefore, the government had to assume the "onerous duty of ... guardianship"

- The title of the 1869 of Act, "Act for the Gradual Enfranchisement of Indians, the Better Management of Indian Affairs," indicates its dedication to assimilation

- The Indian Act strictly limited band council authority and the powers of the council to make laws for communities were limited to such a degree that they were no longer meaningful ways self-governing

- For the sake of the government's assimilative mission, the independence of community leaders was to be ended

- In the second Act, the Consolidated Indian Act of 1876, the constitutional formula of 1869 was repeated with the implication that First Nations would lose control of almost every aspect of their communities

- Two paths were laid out and maintained unquestioningly until after the Second World War: one for non-Aboriginal Canadians of full participation in the affairs of their community, province and nation; and one for First Nations people stripped of the power of self determination, separated from provincial and national life and existing in communities whose colonization was profound and immutable

- Under the Indian Acts of the pre-Second World War period, First Nations people could join the national community only as enfranchised, assimilated individuals. In a sense they were meant to be immigrants in their own land moving not across an ocean but across constitutional jurisdictions from a federally controlled reserve to a province

- The creation of Indian status denied First Nations' people the power to determine, for themselves, who belonged to their communities 
- The "Indian status" created in the Indian Act grew out of Victorian cultural assumptions: that property ownership was the foundation of civilized society and that both ownership and decent of property were attached, primarily, to men

- The Acts before and after the war maintained the dominance of federal authority and, after 1951, sanctioned "legislative inference" by provinces, many of which felt they had no constitutional obligations to First Nation Canadians, had little time or concern for them, and few funds

- Trudeau/Chretien White Paper proposed total and immediate integration; federal authority, the treaties, and the Indian Act were to be rolled up and First Nations communities and individuals would be passed into the care of the provinces. The White Paper was strongly rejected

Steckley, J. L. and Bryan D. C. (2008). Chapter Twelve: The Royal Proclamation and the Indian Act. Full Circle: Canada's First Nations. Second Ed. Toronto: Pearson Prentice Hall, 121-131.

- After the Treaty of Paris, which concluded the Seven Years War with France, British King George III issued the Royal Proclamation of 1763 (p. 121), stating that any lands within the territorial confines of the new governments that had not been ceded by the Indians "are reserved to them, or any of them as their Hunting Grounds." (p. 121)

- To prevent fraud, the proclamation provided a way in which lands could be acquired for settlement

- Indian Act has existed as a tool of a large government bureaucracy "to deal" with Indigenous people

- The administration of Natives was in the hands of the military, reflecting the role and importance of Native people in inter European wars. After the American War of Independence and the War of 1812, European settlers believed that Natives posed a potential threat to them

- Agrarianization and christianization were seen as the best means of "civilizing" Indians

- Not until 1860 did Britain assign full control of Indian matters to the colonies

- In 1867, the British North America Act explicitly made "Indians and lands reserved for Indians" a federal responsibility

- In 1880, a separate Indian Affairs Department was setup under John A. Macdonald, who was both Minister of the Interior and prime minister at the time

- Indian Act banned traditional ceremonies and dances up until 1951

- Indian agents, who were white and male and required no formal qualifications, enforced laws that banned, for example, dressing traditionally off reserve without their permission

- Indian Agents were given a great deal of discretionary power to control various aspects of people's lives by denying them access to sell the corps they had grown to issuing food vouchers

- Indian Act discriminated against women as section 12 (1)(b) denied registration to "a woman who married a person who is not an Indian ... her children would 
likewise not have status, unlike the children of White women who married Status Indian men" (p. 125)

- The United Nations condemned Canada in 1981 after Sandra Lovelace of the Tobique Reserve in New Brunswick complained that she was denied the right to live on her reserve after her failed marriage to a non-Native. Finally, the discriminatory clause was removed with the passage of Bill C-31 in 1985

- Enfranchisement was the loss of Indian status upon acquisition of the right to vote and full citizenship. This whole process goes back to 1857, when the United Canada passed a law titled "An Act of the Gradual Civilization of the Indian Tribes in the Canadas" as a means of granting full citizenship to Native people

- If a Native could speak, read, and write in English, was in good moral character, free of debt, and advanced in elementary branches of education they were to be reported to the governor who could then declare "that such Indian is enfranchised under this Act ... and thereof" (p. 127)

- If a Native met the criteria, he was put on probation for a year, granted 20 hectares of land, and given full citizenship after one year

- Canada gave up enfranchisement in 1985 with the passage of Bill C-31

- The Indian Act was amended so that people who had given up status could regain it

\section{The Pass System 1884-1941}

Smith, J. (2016). 'The Pass System' explores dark chapter in Canadian history. The Toronto Star. Retrieved from https://www.thestar.com/news/canada/2016/01/10/the-pass-system-exploresdark-chapter-in-canadian-history.html

- The Pass System was a policy that segregated First Nations to the reserve

- This policy prevented Indigenous people from leaving the reserve without having an authorized Pass that was signed by an Indian Agent

- In order to get an authorized Pass from the Agent, there had to be a legitimate reason in order for a pass to be issued. The Pass was given a specific time frame. Otherwise, a person could be jailed

- Passes were only given out for hunting, never to attend cultural ceremonies or to attend children in Residential Schools.

- The Pass System would strengthen the Indian Act imposed on First Nations

- This solidified the Indian Act from First Nations to even think of getting legal advice in regards to their lands and resources

- This prevented First Nations from surveying, exploring, and protecting their land from exploitation without their knowledge and from inquiring about the infrastructure and business conducted on their lands

- The Pass System prevented First Nations from being successful on their own lands, condemning them from travelling to markets to sell their crops for profit

- The Pass System was motivated by the settlement of the Prairies, the construction of the railway, the Northwest Rebellion, and by white settlers who 
were complaining that First Nations had an unfair advantage to the land when it came to farming their crops

- Even among First Nations and Canadian society today very little is known about the Pass System and the policies surrounding its implementation

Currie, R. (2016). The Pass System: Segregation in Canada. Circles for Reconciliation. Retrieved from http://circlesforreconciliation.ca/2016/10/12/the-pass-system-gathering-theme/

- The federal government said that some records of the Pass System were destroyed before anyone knew of their historical value

\section{$\underline{\text { Toronto Purchase Claim }}$}

Bellegarde, D. Fullerton, K., Robinson, P., Lickers, K. (2003). Indian Claims Commission: Mississaugas of the New Credit First Nation Inquiry Toronto Purchase Claim. Retrieved from http://publications.gc.ca/collections/Collection/RC31-172003E.pdf

- In June 1986, the Mississauga Tribal Claims Council submitted a number of claims, including the Toronto Purchase claim, to the Specific Claims Branch of the Department of Indian Affairs and Northern Development (DIAND). The claims were submitted on behalf of five First Nations, one of which was the Mississaugas of the New Credit. The claim in respect of the Toronto Purchase alleges that a vast expanse of land in southern Ontario, which includes Metropolitan Toronto, had never been properly surrendered to the Crown. It also alleged that the transactions concerning the purchase, which took place in 1787 and 1805 , were tainted by breaches of the fiduciary duty owed by the Crown to the Mississauga Nation

- The Mississaugas, a branch of the Ojibwa or Chippewa Indians, were occupying lands on the north shore of Lake Huron when they first encountered Europeans in the early $17^{\text {th }}$ century. To the south of the Mississaugas resided the Hurons, who at that time inhabited the lands around Georgian Bay to the north shore of Lake Ontario. Across Lake Ontario, in present-day New York State, lay the territory of the Iroquois, who were organized into a confederacy of Five Nations.

Suzanne. (2012). 'Toronto' is an Iroquois Word. Dragonfly Consulting Services Canada. Retrieved from http://dragonflycanada.ca/toronto-is-an-iroquois-word/

- The colonists realized that Toronto was a well-protected site, perfect for Loyalists and other settlers; it also provided passage north to more abundant hunting grounds that would ensure the survival of the fur trade

- Colonists entered into approximately 20 different agreements with various Mississauga groups, and, in 1787, arranged the Toronto Purchase, paying three groups of Mississauga 1700 in cash and goods, which they later claimed gave 
them the rights to over 1,000 square kilometres of Toronto, including York Region, Vaughan, and King Township

- By 1847 the Mississauga were reduced in numbers (and therefore influence) and have given up much of the land they had received under these agreements

- When a group of Mississauga were forced from their village on the banks of the Credit River, they purchased reserve land from the Haudenosaunee at the Six Nations of the grand River community, which had been created in 1784 under the Haldimand Treaty, and settled there, naming themselves "the Mississauga of the New Credit"

- This group acknowledges Toronto as "Mississauga Territory"

\section{The Royal Commission on Aboriginal Peoples 1996}

Indigenous and Northern Affairs Canada. (2010). Highlights from the Report of the Royal Commission on Aboriginal Peoples. Government of Canada. Retrieved from http://www.aadnc-aandc.gc.ca/eng/1100100014597/1100100014637\#chp8

- The Royal Commission on Aboriginal peoples is a policy that investigated the relationship between Indigenous peoples and the Canadian government

\section{The Truth and Reconciliation Commission}

The Truth and Reconciliation Commission of Canada. (2008). Government of Canada. Retrieved from http://www.trc.ca/websites/trcinstitution/index.php?p=4

- A policy designed to inform all Canadians about the dark history and legacy of Indian Residential Schools (IRS)

\section{Principles respecting the Government of Canada's relationship with Indigenous peoples}

Department of Justice. (2018) 10 Principles Respecting the Government of Canada's Relationship with Indigenous Peoples. Retrieved from http://www.justice.gc.ca/eng/csj-sjc/principles-principes.html

- The Government of Canada is committed to moving forward with Indigenous peoples in regards to their unique relationship regarding rights to selfdetermination, treaties, and reconciliation

\section{The Truth and Reconciliation Calls to Action 2015}

The Truth and Reconciliation Commission of Canada. (2015). Truth and Reconciliation Commission of Canada: Calls to Action. Retrieved from http://www.trc.ca/websites/trcinstitution/File/2015/Findings/Calls to Action English2 .pdf 
- This document provides information about the calls to action that the federal government of Canada needs to address

- Two specific actions \#93 and \#94 deal with calls to action in relation to newcomers (p. $10 \& 11)$

\section{FIELD TRIP STATIONS}

\section{STATION 1: Star Blanket Resources}

Sloan, W. (2018, March). Joanne Dallaire: Never wavering from her truth. Ryerson Today. Retrieved from https://www.ryerson.ca/news-events/news/2018/03/joannedallaire-never-wavering-from-her-truth/

- Ryerson was given the blanket as a gift in 2010 due to Ryerson responding to the TRC report

- The blanket was given to show the responsibility of Ryerson officials in responding to the Truth and Reconciliation Commission Report

- Represents a gesture of peace and goodwill

- During the ceremony Ryerson's President (Mohamaed Lachemi) and Provost and Vice-President (Michael Banarrock) were wrapped in the blanket

- Joanne Dallaire, Ryerson Elder from Shadow Hawk Woman of the Wolf Clan, a Cree Omushkeego with ancestry from Attawapiskat, Ontario stated: "to be wrapped in a star blanket-people who aren't from Indigenous communities might not grasp the tremendous importance of what that means" "that something that is very rarely done, and it's not done easily - there has been a lot of work done. So it's big that Ryerson is making this commitment."

Ryerson University Office of the Vice-President, Equity \& Community Inclusion. (2018, January). Truth and Reconciliation at Ryerson University: Building a New Foundation for Generations to Come. Community Consultation Summary Report. 1-20. Retrieved from:https://www.ryerson.ca/content/dam/aboriginal-news/Truthand-Reconcilation-Community-Consultation-Report-AODA.pdf

- The blanket was given to mark the beginning of a new relationship between Ryerson and the Aboriginal community of Toronto

Script posted within the blanket frame at Ryerson:

"This traditional star blanket, handcrafted by Colleen Ironman, was presented by the Aboriginal Education Council (2010) to Ryerson in recognition of the University's ongoing support and development of Aboriginal education and inclusion."

O'Neil Green, D., Dallaire, J. (2018). Truth and Reconciliation at Ryerson University: Building a New Foundation for Generations to Come. Community Consultation Summary Report. 1-20. Retrieved from https://www.ryerson.ca/content/dam/aboriginal-news/aboriginal-report-web.pdf 
- A major theme presented in this report is an increase in Indigenous visibility at Ryerson and honor the Indigenous history and cultures through symbolic gestures such as formal statements of apology and expressions of reconciliation

\section{STATION 2: Dundas Square/Yonge St.}

Johnson, J. (May 2018). First Story Toronto: Exploring the Indigenous History of Toronto Walking Tour.

- John Grave Simcoe was the lieutenant Governor of Upper Canada during the colonial regime

- He was looking for a route to St. Lawrence, many of these routes were already established by Indigenous people

- Lake Ontario to Lake Simcoe portage route was used for 2,000 years as it was the fastest route, so Simcoe thought it would be a good route for the highway

- When Simcoe met a group of Mississauga's along the route, they inform him about a faster route

- Simcoe decides to build a colonial road as straight as possible at all costs and named it after Young, an Official back in Britain

- Simcoe had a survey dilemma as he wanted it to be a straight road so he hired Augustus Jones as the surveyor and constructor of the new road

- He wanted a road from the newly planned settlement of York, Upper Canada to Lake Simcoe

- Augustus Jones was assisted by a Chief from the Mississauga's, Wabakinine, to help him lay the compass line 30 miles north to lake Simcoe

- In the 1790s, Chief Wasbasi created the route 200 yards from the exact point they wanted to be at

- You can see the 200 yard difference in one spot along Yonge St. where it seems to bend off the path a bit

Bonikowsky, L. (2012 February). Yonge Street- Governor Simcoe’s Military Road. Historica Canada. Retrieved from http://www.thecanadianencyclopedia.ca/en/article/yonge-street-governor- simcoesmilitary-road-feature/

- Simcoe proposed the 'military street' as a strategic route to help protect Upper Canada form American invasion.

- Yonge Street was known as "the longest street in the world" when it was completed in February 20, 1796

- The town of York was created from Loyalists moving northward along the upper St. Lawrence and lower Great Lakes which led to the creation of Upper Canada and York, known as Toronto

- When war broke out between England and France in 1793, Simcoe realized that capital Newark (Niagara on the lake) and its Lake Erie trade route would be vulnerable to attack if America decided to support its French allies.

- Simcoe transferred the capital to Toronto Bay and founded York as the capital 
- Simcoe planned major roads, knowing their value for defence and for expanding development

- Governor's Road (Dundas Street) would run West to the Detroit River and Yonge Street would go North to the Holland River, creating a link with Georgian Bay on Lake Huron and Michilimackinac

- Simcoe set off on September 25, 1793 with a group of soldiers and native guides to explore north of Lake Ontario, following the Carrying Place Trail, a portage route running $45 \mathrm{~km}$ from Lake Ontario to Lake Simcoe, following the Humber and Holland Rivers. The trail was a necessary route, since the Humber's shallow water was often a difficult route to navigate, it froze solid in the winter and its steep bank offered little defence against attack

- Simcoe's strategic route did not follow the natural contours of the land. It was truly a military road, running as straight as an arrow from York to Holland landing. Simcoe named the road Yonge Street, after Sir George Yonge, secretary of war in the British Cabinet and a family friend

- Today, the habour front shore plains remains Toronto's downtown core and Simcoe's military street stretches some $1,900 \mathrm{~km}$

Mealing, S. (2006 July). John Graves Simcoe. Historica Canada. Retrieved from https://www.thecanadianencyclopedia.ca/en/article/john-graves-simcoe/

- Biography of John Graves Simcoe's life

Lee, A. (2018 April). The Meaning of Yonge Street, Toronto's Civic Spine. Maclean's. Retrieved from https://www.macleans.ca/opinion/the-meaning-of-torontos-yongestreet/

- An Indigenous pathway that became popular among fur traders, the trail allowed for strenuous portaging from the mouth of the Humber River to the Holland, which connected Lake Ontario with Lake Simcoe. It was a channel for coureurs du bois like Etienne Brule and for Jesuit missionaries to bring Christianity to the so-called New World

- 178 years after its first recorded use by Samuel de Champlain's Huron allies, it was supplanted by the construction of John Graves Simcoe's new military road, Yonge Street, named after Simcoe's family friend, British war secretary Sir George Yonge.

- A long road between Lake Ontario and Lake Huron would allow, Simcoe hoped, for the sustained success and defense of a new temporary capital of Upper Canada - an upstart colony called York, named after the second song of King George III

Robinson, K. (2017 June). Toronto tour takes a walk through the city's Indigenous history. The Globe and Mail. Retrieved from https://www.theglobeandmail.com/news/toronto/toronto-tour-takes-a-walk-throughthe-citys-indigenous-history/article35270967/ 
- Yonge and Dundas was once part of a major portage route used by Indigenous people

- The Toronto Carrying Place was the most important First Nations trail in Southern Ontario and the main route connecting Lake Ontario with Lake Simcoe and the Northern Great Lakes

- The Carry Place Trail was a vital trade route for the First Nations and also later by the French and English settlers

Turner, G. (2015). The Toronto Carrying Place: Rediscovering Toronto's most ancient trail Toronto:Dundurn. Simplified information for the book is located at http://www.torontocarryingplace.ca/about-the-trail

- The Toronto Carrying Place was a Native trail that led from the mouth of the Humber River on Lake Ontario to the Holland River near Lake Simcoe. For much of its $45 \mathrm{~km}$ ( 26 miles)

- It was an alternative to the more traditional route up the Ottawa River and was particularly useful to the peoples living north and south of Lake Ontario.

- At the time of contact with Europeans, the Toronto Carrying Place was used by the Wendat (Huron), Onondawahgah (Seneca), and later by the Mississauga First Nations. Étienne Brûlé may have been the first European on the Carrying Place, and the trail was extensively used by European explorers, traders, priests, and officials from 1615 until the early 1800s.

- Though quickly supplanted by Yonge Street, the Carrying Place had an enormous influence on the growth of Toronto and Southern Ontario. The Colonial settlement of York - later renamed Toronto - was founded largely because of the Carrying Place's easy access into the Northwest

\section{STATION 3: Image Centre-Indigenous Artists}

Scotiabank. (2018). The Ryerson Image Centre showcases three contemporary Indigenous artists at this year's Scotiabank CONTACT Photography Festival. Retrieved from https://www.newswire.ca/news-releases/the-ryerson-image-centreshowcases-three-contemporary-indigenous-artists-at-this-years-scotiabank-contactphotography-festival-679507233.html

- April to August 2018 the Image Center presented work by three contemporary Indigenous artists: Shelley Niro, Nadia Myre, and Scott Benesiinaabandan

- Collectively, these artists explore notions of culture, identity, and the complex colonial histories of Indigenous people using photography, film, and new media

- Paul Roth, Director of the Ryerson Image Centre: "Artists are often able to address society's most difficult and contentious issues in ways that resonate with a wide audience. Ryerson University is deeply committed to learning from the recommendations of Canada's Truth and Reconciliation Commission, and these exhibitions follow that same path."

- Shelly Niro is a member of the Six Nations Reserve, Bay of Quinte Mohawk, Turtle Clan, Niro combines beadwork designs, archival images, family pictures, 
videos, and installations to question traditional representations of Indigenous peoples, with a particular focus on womanhood. She received the Scotiabank photography award

- Scott explores the historical complexities that are often buried under the metaphorical weight of monuments that commemorate colonial stories

- His artwork was outside as his abstract imagery in the form of a shadow-like silhouette was adhered to the sidewalk adjacent to Ryerson University's contested Egerton Ryerson statue. Other fragmented patterns were conformed to the irregular surfaces of the boulders in nearby Devonian Pond, recalling Indigenous petroglyphs and ancient ceremonial sites

- Nadia Myre's silent video "Acts that Fade Away" presents the artist's hands and forearms filmed from above as she carefully manipulates the needles, threads, patterns, beads, and tools necessary to craft four Indigenous-inspired objects. These include a pair of baby moccasins, a small basket, a woman's hair bonnet, and a bandolier bag - guided only by instructions pulled from nineteenth-century women's magazines. Through the reappropriation of instructions and gestures drawn from European and North American illustrated publications, Myre reclaims Indigenous skills and crafts devalued by colonization

Rubenstein, B. (2017). Scotiabank Contact Photography Festival. Retrieved from https://scotiabankcontactphoto.com/archive/2017/publicinstallation/ryerson-university-devonian-square-asiniy-iskwew

- Lori Blondeau celebrated Plains Indigenous rock formations, significant ancient sites created for sacred and rite of passage ceremonies and for recording battles and histories

- She uses oral histories of Mistaseni a 400-tonne sacred boulder marking an important Indigenous gathering place that the Saskatchewan government dynamited in 1966 to make room for a man-made lake

- The artwork portrayed the artist in red upon glacial boulders, her figure represents resilience of Indigenous cultures

- The artwork is placed on two billion year old boulders imported from the Canadian Shield in Devonian Square within the man made pond on Ryerson's campus

- She occupies the site as if summoning its spirits and proclaims (her) Indigenous history and irrefutable connection to the land

\section{STATION 4: Egerton Ryerson Statue and TRC plaque}

Ryerson University's Aboriginal Education Council (2010, August). Egerton Ryerson, the Residential School System and Truth and Reconciliation. 1-7. Retrieved from https://www.ryerson.ca/aec/about/

- Additional resources are listed at the end of this document

- Egerton Ryerson was a $19^{\text {th }}$ century Canadian who played an important role in politics, religion, arts, sciences, and education 
- Ryerson was named after Egerton because of his influence in creating free and compulsory public education system, the Ryerson name was created in 1948

- He created the Normal School, Toronto's first teacher's college in mid-1800s, the façade forms the entrance to the University's Recreation and Athletic Centre

- He believed in different systems of education for White and Aboriginal children

- The beliefs played a role in the establishment of Residential School System

- Ironically, he supported separating the Church and state within education but within residential schools he believed the government and churches should be partners

- Residential schools were first called manual labour schools, industrial schools, and boarding schools

- Egerton Ryerson was the Chief Superintendent of Education in Upper Canada at the time

- He explained that the end goal was not for learning but to make industrious farmers

- Most of his suggestions were taken seriously as he was influential within the area of education

- Ryerson was involved in a report on Industrial Schools for Indians and Half Breeds, which was used to convince McDonald government to begin industrial schools in the 1800s

- Residential schools primary objectives were to remove and isolate Indigenous children from their culture, tradition, language, community, parenting skills that is still felt by the Indigenous community through Intergenerational trauma where the results have been addiction, suicide, and loss of self-identity

- Residential schools "denied their identities, languages and cultures as Aboriginal people which is known as "cultural genocide"' (p. 4)

- Ryerson University is committed to acknowledging the role Egerton Ryerson had in conceptualizing residential schools and is committed to welcoming and respecting Aboriginal people

Ryerson, E. (1847). Report by Dr. Ryerson on industrial schools, appendix A. In Statistics respecting Indian schools. Ottawa: Government Printing Bureau, 1898.

- Egerton wrote a letter to George Vardon, assistant superintendent of Indian Affairs

- The letter stated that nothing could be done for Aboriginal people other than to make "the Indian a sober and industrious man" (p. 73)

- He explained that "it is a fact established by numerous experiments, that the North American Indian cannot be civilized or preserved in a state of civilization (including habits of industry and sobriety) except in connection with, if not by the influence of, not only religious instruction and sentiment but of religious feelings" (p. 73) 
O'Neil Green, D., Dallaire, J. (2018). Truth and Reconciliation at Ryerson University: Building a New Foundation for Generations to Come. Community Consultation Summary Report. 1-20. Retrieved from https://www.ryerson.ca/content/dam/aboriginal-news/aboriginal-report-web.pdf

- After Ryerson acknowledged Egerton Ryerson's involvement in creating residential schools a healing ceremony took place and Ryerson was gifted the Star Blanket which marked a positive move forward in the relationship between Ryerson and the Indigenous community of Toronto

- Plaque for the statue of Egerton Ryerson was unveiled in 2018, outlining Ryerson's participation in the establishment of residential system in Canada and the harm that was caused by the system that robbed many Indigenous Peoples of their culture and left them with psychological, emotional, and physical damage

\section{Ryerson TRC Plaque:}

Alozzi, R. (2018). Ryerson Unveils Plaque Recognizing its Racist History. The Eye Opener. Retrieved from https://theeyeopener.com/2018/06/ryerson-unveils-plaquerecognizing-its-racist-history/

- Beside the Egerton Statue a Truth and Reconciliation plaque was unveiled on June 25 2018 to recognize Egerton Ryerson's namesake and his role in Canada's racist residential school system

- The ceremony for the plaque does not mark a beginning or an end, but a step towards a long process of reconciliation

Sloan, W. (2018). Plaque Unveiling a Step Towards Truth and Reconciliation. Ryerson Today. Retrieved from https://www.ryerson.ca/news-events/news/2018/07/plaqueunveiling-a-step-towards-truth-and-reconcilliation/

- Ryerson community has installed a plaque by the statue of Egerton Ryerson, contextualizing his role in the creation of Canada's residential school system

- The plaque reads, "This plaque serves as a reminder of Ryerson University's commitment to moving forward in the spirit of truth and reconciliation. Egerton Ryerson is widely known for his contributions to Ontario's public educational system. As Chief Superintendent of Education, Ryerson's recommendations were instrumental in the design and implementation of the Indian Residential School System. In 2015, the Truth and Reconciliation Commission reported that children in the schools were subjected to unthinkable abuse and neglect, to medical experimentation, punishment for the practice of cultures or languages and death. The aim of Residential School System was cultural genocide"

- The Truth and Reconciliation Commission estimates that there are 80,000 survivors and the passing on of unresolved trauma created an intergenerational legacy of the residential school system

- Today, Aboriginal survivors, their children, grandchildren and communities are engaged in healing processes to recognize the history and impacts of this 
education system on Aboriginal peoples and support aboriginal communities in reclaiming their identities

- "The words serve as a reminder to all passersby of Ryerson University's commitment to moving forward in the spirit of truth and reconciliation. And we cannot have reconciliation if we're not away of the truth" said Denise O'Neil Green, Vice President, Equity and Community Inclusion

- Senator Sinclair said, "it was education that got us into this mess - it's going to be education that gets us out of it,' and Ryerson is leading the way"

\section{Information on Residential Schools}

Aboriginal Healing Foundation (2002). Research series. Retrieved from http://www.ahf.ca/publications/research-series

- 150,000 aboriginal children forced into residential schools

- $15-24 \%$ died each year

- Within these schools medical experiments were conducted on many children

- Many children suffered from verbal, physical, and/or sexual abuse

Rheault, D. (2011). Solving the "Indian Problem": Assimilation Laws, Practices and Indian Residential Schools. 1-6. Retrieved from https://www.omfrc.org/wpcontent/uploads/2016/06/specialedition8.pdf

- Four policy alternatives were used to solve the "Indian question:" 1. extermination; 2. slavery; 3 . insulation (reserves); 4. assimilation

- Bagot Commission report proposed federally run residential schools as good tools for separating children from their parents and forcing Aboriginal peoples away from their traditional life

- 1867 Constitution Act, reinforced the policy of assimilation designed to change Native people from savage to civilized

- children were forcibly taken from their families by priests, Indian agents, and police officers

- students were discouraged and often ordered out of school by officials by the age of 16.

- The 2001 Truth Commission into Genocide in Canada documents the death of more than 50,000 Native children in residential school system by the Roman Catholic church, the United Church of Canada, the Anglican Church of Canada, and the federal government

- children were killed by beating, poisoning, electric shock, starvation, prolonged exposure to sub-zero cold while naked, and medical experimentation

- Residential school syndrome, a combination of historical trauma and a sub-type of post traumatic stress disorder has been found due to these schools

Canadian Human Rights Tribunal. (2016). First Nations Child and Family Caring Society of Canada and Assembly of First Nations and Canadian Human Rights Commission and Attorney General of Canada and Chiefs of Ontario and 
Amnesty International Decision. 1-176. Retrieved from http://s3.documentcloud.org/documents/2698184/Jugement.pdf

- The federal government of Canada didn't acknowledge this history until 2008

- Two primary objectives of residential school was to remove and isolate Indigenous children from the influence their homes, families, traditions and cultures, and to be assimilated into the dominant culture

- During this era, Indigenous children were often forcibly removed from their homes and brought to residential schools to be "civilized"

- Living conditions were appalling and often caused disease, hunger, stress, and despair

- Many children were physically, verbally, and/or sexually abused at these schools

- If children spoke their Native language they would often be physically punished

- Some children were locked in closets, cages, basements, and forced to eat their own vomit

- Some children managed to run away but many who did in the winter months died in the cold weather

- Many children in residential schools and adults who have experienced residential schools have committed suicide

- These schools have created intergenerational trauma, which passes on from generation to generation

- Some effects of intergenerational trauma are suicide, addiction, and loss of self identity

\section{STATION 5: Ryerson Athletic Centre}

Toronto Native Community History Project. First. (2018). First Story Toronto Stories. Driftscape App. [Mobile Application Software]. Retrieved from https://play.google.com/store/apps/details?id=ca.comap.firststory\&hl=en CA

\section{George Armstrong:}

- Irish and Algonquin heritage

- Played for NHL on original six teams

- Longest serving captain of Toronto Maple Leafs

- 1950 he was given the nickname "Chief shoot the puck" by a Native Canadian tribe in Alberta

- "Chief" stuck because of his leadership skills

- Captain for 13 of 21 seasons in the league

- The team accepted the Stanley cup in 1962, 63, 64 and 67

- After retiring he spent time coaching Toronto Marlboros

- He was inducted into the Hockey Hall of Fame in 1975

\section{Chicago Blackhawks:}

- The logo for the Blackhawks, a stoci Indigenous man with feathers in his hair, has became one of the most cherished and controversial logos in the league 
- First Indigenous NHL player played for the Chicago Blackhawks, Fred Sasakamoose

- He was from a Cree community in Saskatchewan

- He was a residential school survivor

- His first game was in Toronto in 1953

- Fred was a part of a special puck ceremony at the Rexall Place in 2014 at age 80

\section{Canada's National Sport- Lacrosse:}

Campbell, M. (2017 July). How Indigenous people in Canada are reclaiming lacrosse. Maclean's. Retrieved from https://www.macleans.ca/society/how-indigenouscanadians-are-reclaiming-lacrosse/

- 1700s: Mohawk men near present day Montreal were first to play tewaaarathon, a ball and net stick game that was given to them by the Creator and taken from them by Canadian settlers

- English dentist changed the rules and banned Aboriginal athletes from rosters

Simpson, H. A Brief History of Lacrosse in Canada. Culture Trip. Retrieved from https://theculturetrip.com/north-america/canada/articles/a-brief-history-oflacrosse-in-canada/

- Algonquin named the game Baggataway

- Iroquois Nation named it Tewaaarathon

- The game was played as a way to show gratitude to the Great Spirit

- Lacrosse name came from French settlers who believed the stick looked like a Bishops crozier or staff. Crozier in French is crosse which is why they began to call it La Crosse

- 1800 s Montreal residents became interested in the sport and begin to play against First Nations

- William George Beers produced a pamphlet on the sport in 1860 that changed the rules and instructions

- Lacrosse became Canada's national game in 1858 but in 1994 it became the national summer sport while hockey became the national winter sport

Claydon, J. Origin \& History. Federation of International Lacrosse. Retrieved from https://filacrosse.com/fil/origin-history/

- The game was initially played by St. Lawrence Valley area Algonquian tribes and they were followed by other tribes in the Eastern half of North America and around Western Great Lakes

- Usually they were major events that took place over days

- Games were played across huge fields up to 500 yards to several miles apart

- Large numbers of Indigenous people would play

- Rules were that the ball was not to be touched by a player's hand and there were no boundaries 
- Games were played for the creator as well as to toughen up young warriors for war and for recreation

- The first settler to see the sport being played was a French Jesuit Missionary, Jean de Brebeuf

- A dentist, William George Beers, was responsible for changing the rules of the game so that only a certain number of people could play and he changed the ball from a deerskin ball or wooden ball to a rubber ball

- In 1883 a touring team of Iroquois natives visited Scotland to play. Promotional literature was given out during these events to promote emigration to Canada

\section{STATION 6: Ryerson Aboriginal Student Services (RASS)}

Ryerson University Office of the Vice-President, Equity \& Community Inclusion. (2018, January). Truth and Reconciliation at Ryerson University: Building a New Foundation for Generations to Come. Community Consultation Summary Report. 1-20. Retrieved from https://www.ryerson.ca/equity/initiatives/truth-reconciliation/

- RASS was initiated in 1993 by Monica McKay (Nisga'a Nation)

- The services are provided in a holistic, responsive model of support

- 2010 Ryerson established a University Advisory Council on Aboriginal issues and Education (AEC), which is committed to developing a new relationship of truth and reconciliation between Indigenous and non-Indigenous peoples at Ryerson

- On May $7^{\text {th }}, 2012$ Ryerson University and RASS were presented with the Eagle Staff

- The Eagle Staff was given for leadership within Aboriginal learning and education. It is present at significant university events such as convocation and remembrance ceremonies

Aboriginal Education Council. (2016). About the AEC. Retrieved from https://www.ryerson.ca/aec/about/

- May 182016 RASS and AEC received a buffalo skull from the Centre for Aboriginal Student Services at York University

- The skull was given to recognize the work RASS and AEC does for Aboriginal learners

- RASS and AEC are expected to gift forward to another post-secondary institution to create a new ceremonial tradition

\section{Aboriginal Education Council:}

Aboriginal Education Council. (2014). Ryerson University Aboriginal Education Council Terms of Reference. Retrieved from https://www.ryerson.ca/content/dam/aec/pdfs/AEC-TOR-Nov-2014-FINAL.pdf

- This council was created in 2010 as part of the Aboriginal Post-Secondary Education Training (PSET) 
- It works to include Aboriginal worldviews and values in its operations

- Their vision "is to ensure that the next seven generations of Aboriginal people including students, faculty and staff have greater opportunities and success in education at Ryerson University" (p. 1)

- Focus is on developing a continued relationship of truth and reconciliation between Aboriginal and non-Aboriginal people

- $\mathrm{AEC}$ is involved in decision making that involves Aboriginal education at Ryerson, provides leadership on the curriculum in relation to Aboriginal content and how it is to be delivered, provides guidance on student recruitment and retention as well as many other tasks

\section{STATION 7: Birch Trees}

Croft, S., \& Mathewes, R. W. (2013). BARKING UP THE RIGHT TREE: Understanding birch bark artifacts from the canadian plateau, British Columbia. BC Studies, (180), 83. 1-20.

- Birch bark can be used for wrapping and storing meat and fish because it prevents rot

- Birch bark artifacts made by pre-contact hunter gatherers have been recovered from Plateau contexts

- Women collected, prepared, and transformed plant materials such as birch bark into basketry and woven manufactures

- Men would often harvest birch bark for birch bark canoes they made

- Birch bark was often harvested in such as way as to ensure the inner cambium layer remained intact and that the tree was not killed

- If tough, thick and durable bark was needed, such as for the construction of toboggans it could be peeled off in large sheets during the cold winter months in January and February

- After winter, the bark becomes fragile, thin and peels easily as the xylem and phloem begin to actively run in late spring to early summer; this is the time when bark can be stripped for use as paper

Marsh, W. (2016). Traditional Uses of Birch Bark in Canada. Escape, Explore, Experience. Retrieved from https://www.wyemarsh.com/traditional-uses-of-birchbark-in-canada

- Birch bark canoe is an iconic artifact in Canadian history as a principal means of water transportation

- The lightweight yet strong bark was perfect for canoes, which helped distant communities to connect to facilitate trade and commerce, communication, and cultural exchange and to explore the landscape

- Bowls and baskets were made from birch bark to store food

- Bark was used as a substance to write on

- Algonquin First Nations peoples used birch bark to cover their homes, wigwams 
- Birch bark biting is the practice of perforating paper-thin birch bark in the fabrication of containers, artistic designs, and pictographic scrolls

- Ojibwa, Cree, and other Algonquin First Nations people often performed birch bark biting

- Birch-bark biting was especially helpful for quillwork to decorate clothing and moccasins, and items such as drums, boxes, pipes, and tipis and wigwams

- Some used the leaves and bark to cure skin related illnesses

- Hunters would use the bark to call out to animals and mimic their sounds to lure in male moose

- Birch bark helped build the country we live in today

Redish, L. (2015). Native American Birch Tree Mythology. Retrieved from http://www.native-languages.org/legends-birch.htm

- Tough, flexible highly waterproof sheets of bark made this tree particularly useful to Indigenous people

- It is used for:

- Exteriors of canoes

- Baskets

- Artwork

- Maps

- Medicine

- Ojibwe folklore say that birch trees are immune to lightning strikes and are therefore good places to hide during storms

Conley, A. How the Birch Tree Got its Burns. An Ojibwe Legend Retold. Retrieved from http://www.uwosh.edu/coehs/cmagproject/ethnomath/legend/legend10.htm

- You can only tell Waynaboozhoo stories in the winter when there is snow on the ground

- Waynaboozhoo's grandmother told him to go get fire because it is winter and they need fire for warmth and cooking. He was told to go get ishkodence, fire that Thunderbird has in the West

- Waynaboozhoo disguised himself as waboos, a little rabbit in hopes of getting fire

- When Waynaboozhoo finally research Thunderbird's home he asked if he could share his warmth and if he could stay for a little while as he was cold and lost

- Thunderbird agreed, when he wasn't looking Waynaboozhoo rolled into the fire and ran away from Thunderbird's home with the fire on his back

- Thunderbird chased after him and threw lightning flashes at Waynaboozhoo. Waynaboozhoo yelled for someone to help him

- Omaaî mitig, the birch tree said, "Come, hide beside me my brother. I will protect you"

- Waynaboozhoo hid under the birch tree as Thunderbird flashed and thundered around him 
- The lightning bolts missed Waynaboozhoo every time but hit Omaaî mitig, the birch tree, every time

- Dark burn marks scarred the white bark of the tree and that is why birch trees have burn marks on their bark

\section{STATION 8: Jarvis Street}

Errett, J. (2016). Was Jarvis Street named after a city-builder, or a slave-owner?

Prepare for a debate. CBC News. Retrieved from

https://www.cbc.ca/news/canada/toronto/jarvis-street-slavery-1.3564667

- Jarvis Street is named after William Jarvis (father) and Samuel Jarvis (son) who had a history of slavery, violence, and inequality

- They were unsavoury characters described as turkeys, incompetent, lazy, selfish, dishonest just to name a few characteristics that can be found in Toronto literature to describe the father and son

- William Jarvis fought to keep his slaves when Lieutenant Governor John Graves Simcoe was seeking to make slavery illegal. Because of Jarvis' opposition the law was watered down to gradually phase out slavery instead of ending it

- When Samuel Jarvis was Chief Superintendent of Indian Affairs for Upper Canada, a position that was handed to him just like everything else, he was caught embezzling some 4,000 pounds from First Nations groups in the area

Johnson, J. (May 2018). First Story Toronto: Exploring the Indigenous History of Toronto Walking Tour.

- Jarvis was apart of a family compact, which were elite wealthy conservative families who controlled affairs of the state

- The Family Compact ran things officially and unofficially

- Samuel Jarvis the son of William Jarvis is who the street is named after

- Samuel expected that he would be given a position in government with little to no effect, which was true

- He wasn't well known for his work ethic or personal qualities

- He was known for his quick temper and irresponsibility with money

- He murdered Thomas Rideout in a duel in 1820s. Thomas called Jarvis out for owing him money as Samuel Jarvis was well known for making poor decision with his money. Jarvis refused to pay him so they had a duel. Thomas fired before he was suppose to which allowed Jarvis to have a free shot, which killed Thomas

- Jarvis became the Chief superintendent of Indian affairs and he was in charge of everything on behalf of Indigenous people. He did nothing but sell Indigenous land

- He had the legal right to do so but as the superintendent he was suppose to put that money in a trust so the community could use the money towards their land but he didn't and put it in his own account 
- Jarvis wasn't good with money; 9,000 pounds went missing so he had to sell his estate to repay the money, although the Indigenous people never saw the money

Hazelburn. Lost Rivers. Retrieved from

http://www.lostrivers.ca/content/points/hazelburn.html

- 1837 Samuel was appointed Chief Superintendent of Indian Affairs

- fives years later, a commission of inquiry investigated his department's activities. Jarvis was dismissed in 1845 after an audit showed he personally owed the government 4,000 pounds

- He began to survey and sell lots of his land

Leighton, D, Burns, R. (1985). Jarvis, Samuel Peters. Dictionary of Canadian Biography. 8, University of Toronto. Retrieved from

http://www.biographi.ca/en/bio/jarvis samuel peters 8E.html

- Samuel Peters Jarvis was the son of William Jarvis and Hannah Peters

- He joined a flank during the War of 1812

- After the war he finished law school

- His volatile and impetuous personality caused problems on many occasions, most notably in 1817 when he quarreled with John Ridout and killed him in a duel

- 1837 he was appointed Chief Superintendent of Indian Affairs for Upper Canada, a position he held until 1845

- he was found to be an incompetent administrator and possibly dishonest

- department accounts were poorly managed, with as much as 9,000 pounds unaccounted for

- In 1842 Governor Sir Charles Bagot established a three man royal commission to inquire into the structure of the Indian Department in the new province of Canada. Its first report, delivered in January 1844, was directly responsible for Jarvis's being stripped of his official rank in all but name that May and for his forced retirement the following year

- Jarvis's attempt to defend himself only resulted in new evidence being gathered against him

- Office of Chief Superintendent was abolished in 1845 and Jarvis' was forced to retire

- The government never forced him to restore the missing funds for which it claimed he was responsible for

- In 1818 his house, Hazelburn, which was built for his family 23 years before, was torn down to make way for the street which still bears Jarvis's name

Andrew-Gee, E. (2015). Toronto Street Signs a Reminder of First Nations Heritage. The Toronto Star. Retrieved from https://www.thestar.com/news/gta/2015/06/02/toronto-street-signs-a-reminder-offirst-nations-heritage.html 
- This article explains the importance of Indigenous place making to restore Indigenous presence in Canadian communities

- New signs in blue and white were put up to rename Spadina and Davenport Rds. to their traditional Ojibwe names Ishpadinaa and Gete-Onigaming

- This project is run by Hayden King, director of the Yellowhead Institute at Ryerson, and Susan Blight, student life co-ordinator at the University of Toronto's First Nations House

- By giving prominence to Ojibwe words, they hope to heal some of the damage caused by educational policies that long discouraged the learning of Aboriginal language

- Ishpadinaa is the word on which "Spadina" is based; it means "a place on a hill"

- Gete-Onigaming means "at the old portage" a reference to Davenport Rd.'s history as a trail between the Don and Humber rivers

- "Toronto" itself comes from a Mohawk word, tkaronto meaning "where there are trees standing in the water"

- The city erases its Aboriginal history which is obvious in relation to the story for Jarvis St.

\section{STATION 9: Miziwe Biik Aboriginal Employment \& Training}

OR Oronhyatekha's (house on the other side of Allen Gardens on Carlton Street)

FirstStoryTO (2013, February). Dr. Oronhytekha. First Story Toronto: Exploring Indigenous History of Toronto. Retrieved from https://firststoryblog.wordpress.com/2013/02/25/dr-oronhytekha/

- Oronhytekha - Burning Cloud - Peter Martin - Dr. O

- He is from a Mohawk family who lived on the Grand River

- He was in a residential school as a child

- He graduated from missionary studies program at Wesleyan Academy in 1856

- He continued religious studies in Ohio and graduated at the top of his class in 1860

- He was chosen by chiefs of Six Nations Council to give a welcoming address to the Prince of Wales upon his visit in 1860

- Welcoming address words come before all else, like a prayer to thank everyone and everything. It's done orally and in their language

- The Prince was so impressed with his presentation he invited Dr. O to study at the University of Oxford in England

- He only completed one semester as he didn't obtain permission from the Church of England's agent to leave the reserve so he was forced to return

- He continued his studies at the University of Toronto

- He received his medical degree in 1867, he was one of the first Aboriginal people to graduate as a medical doctor

- His practices advertised the use of Indian cures and herbal medicine

- In London, Ontario, he began to join many orders such as Orange Order and American based fraternal order of the Independent Order of Foresters (IOF) 
- IOF was stated to be for white males only but Dr. O had status due to being a part of the Orange Order

- As the Supreme Chief Ranger of IOF he extended insurance benefits to thegeneral population not just the wealthy

- He became the leader for IOF which is known today as Foster Insurance Agency

- A life size bronze statue of Oronhyatekha is still present today in the lobby of the current head office of the IOF on Don Mills Road today

- Being Chief Ranger required Dr. O to travel the world. As Dr. O travelled he liked to collect to artifacts. These artifacts were donated to the Royal Ontario Museum

- When he passed away in 1907, his body lay in Massey Hall in Toronto for the public to pay tribute

- On March 6, over 10,000 people came to pay their respects

- He was an activist as he would write to John A. MacDonald about how Indigenous people should have the right to vote and how Indigenous women shouldn't lose their status if they marry a non-indigenous man

- He was actively working for his people at the height of colonialism

- His story is an example of how Indigenous people are not victims but every generation has done what they can to fight on behalf of their people

Doctor Oronhyatekha: A Mohawk of National Historic Significance 1841-1907 Brochure: http://www.mbq-tmt.org/assets/Nation\%20Building/DrObrochure.pdf

- Dr. Oronohyatekha had met royalty, the Emperor of Japan, presidents and prime ministers. He was a justice of the Peace and an ambassador for Canada

- On August 21s 2005 he was recognized as a Canadian Figure of National Historic Significance with plaque erected by the Historic Sites and Monuments Board of Canada

- Legacy of two communities, the Six Nations of Grand River and Tyendinaga Mohawk Territory. He remained true to his heritage, his language, his culture, and to his people throughout his lifetime

- To commemorate Dr. Oronhyatekha's life and contribution to society, a "Dr. Oronhyatekha Memorial Educational Scholarship Fund" has been established to provide scholarships for status Indian students enrolling in a Canadian medical school Dr. Oronhyatekha and his wife Deyoronseh, would have seven children, but only two would survive to adulthood

Hamilton, M. (2017). Canada's first indigenous physician? The Story of Dr. O (18411907). Can J Sung, 60(1), 8-10. Retrieved from

https://www.ncbi.nlm.nih.gov/pmc/articles/PMC5373735/

- In 2005, Parks Canada erected a plaque near Dr. Oronhyatekha's (Burning Sky) grave at the Tyendinaga Mohawk Territory and designated him a national historic person, partially based on the belief that he was the first accredited Indigenous doctor in Canada

- A phrenologists, A. O'Leary toured North America. In 1854, he was in Brantford and visited Oronhyatekha at home. After assessing his skull, O'Leary concluded 
Oronhyatekha should pursue further education, but also offered to take him on tour. Oronhyatekha ended up working at the O'Leary family farm for 5 months before enrolling in school

- The Grand River council chose him as its representative for the 1860 royal visit of the Prince of Wales. Legend says that the prince encouraged Oronhyatekha to join him as a student at Oxford University

- By late 1875, he had been appointed DIA physician for the Oneida of the Thames, and opened a practice in downtown London, Ontario

- In London, he joined the Independent Order of Foresters (IOF), a fraternal organization that offered its members life insurance. First elected medical examiner, Dr. Oronhyatekha quickly moved through the ranks to become the Supreme Chief Ranger in 1881, a position he held until his death

Dr. Oronhyatekha Memorial Educational Scholarship Fund. (2017 August). Doctor Oronhyatekha- A Mohawk of National Historic Significance. Bay of Quinte Tourism.Retrieved from http://www.mbqtmt.org/assets/Nation\%20Building/DrObrochure.pdf

- Oronhyatekha (Burning Sky) was born on August 10, 1841 on the banks of the Grand River, the territory of the Six Nations people, near what is now known as Brantford, Ontario

- During his early years he was educated in the Mohawk language and learned to appreciate the ideals of Mohawk culture and customs

- He attended the Mohawk Institute in Brantford, a residential school where he learned to read and write in English and was trained to be a cobbler

- American phrenologist pronounced Oronhyatekha "educable" [sic] and accompanied him to the United States where he enrolled in college

- He returned home throughout the semesters and taught in day schools at Six Nations until he graduated from Kenyon College, Ohio

- He returned to Six Nations Territory and resumed teaching

- In 1860, the Prince of Wales visited Canada on the first official Royal Visit and the Six Nations Confederacy Council selected him to deliver a Welcoming Address to the young Prince

- He did such a good job the Prince suggested he should study at Oxford University, England

- In 1862, he accepted the invitation and became the first Native person in Canada to study at Oxford

- Oronhyatekha did not obtain permission to leave the reserve nor to attend Oxford and so he was called back to Canada

- He decided to settle at the Tyendinaga Mohawk Territory at the Bay of Quinte

- In this territory he married Deyoronseh also known as Ellen Hill

- Oronhyatekha had decided to pursue a career as a medical doctor and enrolled at a medical school affiliated with the University of Toronto

- He graduated with his medical degree in 1866

- In 1867 he was granted a license to practice physic surgery and midwifery from the newly formed College of Physicians and Surgeons of Ontario 
- Oronhyatekha and his wife would have seven children, but only two would survive to adulthood

- In 1871 Dr. Oronhyatekha earned nine medals for marksmanship at the Wimbeldon Shoots, England

- He began to become involved in politics and in 1872 became the Chairman of the Grand Indian Council of Ontario and Quebec

- In 1873, Oronhyatekha took the position of consulting physician at Tyendinaga after being recommended for the post by Prime Minister Sir John A. Macdonald

- In 1878, Dr. Oronhyatekha joined the fledgling fraternal insurance company, the Independent Order of Foresters (I.O.F.) at London, Ontario

- By 1881, Dr. O became the chief executive officer, the Supreme Chief Ranger, a program he held for 26 years until his death in 1907

- He led I.O.F. to become one of the largest of fraternal insurance companies in Canada, and he would establish it as an international order with offices and "Courts," as they were referred to then, in over 35 countries around the world

- He expanded its membership to include children and women

- Oronhyatekha's collection of over 800 artifacts and natural history specimens from around the world that he had amassed during his lifetime of world travel were exhibited in one of the very first private museums in Canada. Later it would be in the Royal Ontario Museum

- In 1902 Dr. Oronhyatekha suffered heart complications brought about by the ravages of diabetes. He was advised to go to Savannah, Georgia, where he died on March 3rd 1907

- Dr. Oronhyatekha was given a state funeral and laid in Massey Hall, Toronto. Thousands of people lined the streets of the funeral route

- He had profound effect on the social and economic policies of Canada at the time of its greatest changes and growth

- In 1957, he was honored with an Ontario Historical Plaque at his final resting place at Christ Church, Her Majesty's Chapel Royal of the Mohawk, Tyendinaga Mohawk Territory

- On August 2005, he was recognized as a Canadian Figure of National Historic Significance with a plaque erected by the Historic Sites and Monuments Board of Canada

- Dr. Oronhyatekha remained true to his heritage, his language, his culture, and to his people throughout his lifetime

- To commemorate Dr. Oronhyatekha's life and contributions to society, a "Dr. Oronhyatekha Memorial Educational Scholarship Fund" has been established to provide scholarships for status Indian students enrolling in a Canadian medical school

\section{The Plaque in Allan Gardens}

Brown, A. (2008). Oronhyatekha (Burning Cloud). Toronto's Historical Plaques. Retrieved from http://torontoplaques.com/Pages/Oronhyatekha.html 
- 1995 Toronto Historical Board plaque is found on the Southwest corner of Carlton and Sherboune Street

- The information on the plaque is listed on this website

\section{STATION 10: Allan Gardens}

Robinson, K. (2017 June). Toronto tour takes a walk through the city's Indigenous history. The Globe and Mail. Retrieved from

https://www.theglobeandmail.com/news/toronto/toronto-tour-takes-a-walk-throughthe-citys-indigenous-history/article35270967/

- Jarvis and Carlton Street

- The park is known as a meeting place for the Indigenous community in the city

- Northeast of the park on Carlton Street was home of Dr. Oronhyatekha (Dr. O), a Mohawk physician, the CEO of a multinational financial institution and notable figure in the history surrounding British colonization and the Indigenous community

- Dr. O was a strong voice for the rights of women, children and minorities

- He was well known during the Victorian era as he gave many speeches on issues of Indigenous suffrage and social equity

Ricci, T. (2017 December). Idle No More-inspired charity still has impact in Allan Gardens. CBC News. Retrieved from http://www.cbc.ca/news/canada/toronto/idleno-more-allan-gardens-food-

\%20\%20\%20\%20\%20\%20\%20\%20\%20\%20\%20clothing-share-1.4442198

- Allan Gardens Food and Clothing Share is one of the local initiatives sparked by Idle No More

- Founded in 2013, it now is a weekly meeting where hot meals and clothing are made available to those in need

- This happens once a week in Allan Gardens for those in need

Nahwegahbow, B. (2013). All My Relations: A work of art. Windspeaker Publication, 30(10). Retrieved from http://ammsa.com/publications/windspeaker/all-my-relationswork-art

- All My Relations is Indigenous artwork that was placed on the wooden boards that surrounded Allan Gardens during the Gerrard Water main Replacement project, it is no longer present

- Mural was the size of two football fields

- There was a memorial wall for the missing and murdered Aboriginal women

- The wall located on the east side showcased "where all life begins," according to traditional teachings

- Blue water and sky depicted the moon teachings because of the special relationship women have with the moon 
- Award winning artists Tannis Nielsen and Phillip Cote were lead artists for the project

- Themes of the other four paintings were about community, water, Anishnawbe Teachings, and History of the Land

- Dorothy Peters and Alex Jacobs were elders of the project

- Phillip Cote created History of the Land as a part of the mural it shows the birth of the cosmos, the creation of Original Man, the first ceremonies, the renewal of the earth on the back of the turtle, and on until the current time

- This art project brought together 21 members of Toronto's Aboriginal Community together to design and create 5 vignettes to illustrate Aboriginal history in the area (https://allmyrelationsmuralproject.wordpress.com/about/)

Rieti, J. (2018 January). Toronto's Allan Gardens could get a refresh that highlights its Indigenous roots. CBC News. Retrieved from http://www.cbc.ca/news/canada/toronto/allan-gardens-refresh-1.4507953

- There is possible talk about revitalizing Allan Gardens if it is approved by city council

- It is said that Indigenous culture could be front and centre in the revitalization

- The city is working with the Indigenous Place Making Council

- They hope to improve the Palm House, water feature, outdoor café, meeting spaces, and light installations

- Neechi Sharing Circle happens every Thursday in the park with a chance to drum, share songs, and have serious talks

- Claudia Medina from Pasan the community group that creates Neechi Sharing Circle worries that the changes might force people out

- "we make plans in other people's homes" - Claudia Medina 